\title{
Hydrologic landscape classification evaluates streamflow vulnerability to climate change in Oregon, USA
}

\author{
S. G. Leibowitz ${ }^{1}$, R. L. Comeleo ${ }^{1}$, P. J. Wigington Jr. ${ }^{1, *}$, C. P. Weaver ${ }^{2,3}$, P. E. Morefield ${ }^{2}$, E. A. Sproles ${ }^{4, * *}$, and \\ J. L. Ebersole ${ }^{1}$ \\ ${ }^{1}$ US EPA, National Health and Environmental Effects Research Laboratory, Corvallis, Oregon, USA \\ ${ }^{2}$ US EPA, National Center for Environmental Assessment, Washington, D.C., USA \\ ${ }^{3}$ The US Global Change Research Program, Washington, D.C., USA \\ ${ }^{4}$ ORISE post-doc, c/o US EPA, National Health and Environmental Effects Research Laboratory, Corvallis, Oregon, USA \\ * retired \\ ** now at: Centro de Estudios Avanzados en Zonas Áridas, La Serena, Chile
}

Correspondence to: S. G. Leibowitz (leibowitz.scott@epa.gov)

Received: 28 January 2014 - Published in Hydrol. Earth Syst. Sci. Discuss.: 11 March 2014

Revised: 10 July 2014 - Accepted: 30 July 2014 - Published: 5 September 2014

\begin{abstract}
Classification can allow for evaluations of the hydrologic functions of landscapes and their responses to stressors. Here we demonstrate the use of a hydrologic landscape (HL) approach to evaluate vulnerability to potential future climate change at statewide and basin scales in the state of Oregon. The HL classification has five components: climate, seasonality, aquifer permeability, terrain, and soil permeability. We evaluate changes when the 1971-2000 HL climate indices are recalculated using 2041-2070 simulation results from the ECHAM (European Centre HAMburg) and PCM (Parallel Climate Model) climate models with the A2, $\mathrm{A} 1 \mathrm{~b}$, and $\mathrm{B} 1$ emission scenarios. Changes in climate class were modest (4-18\%) statewide. However, there were major changes in seasonality class for five of the six realizations (excluding PCM_B1): Oregon shifts from being $13 \%$ snow-dominated to 4-6\% snow-dominated under these five realizations, representing a 56-68\% reduction in snowmeltdominated area. At the basin scale, simulated changes for the Siletz Basin, in Oregon's Coast Range, include a small switch from very wet to wet climate, with no change in seasonality. However, there is a modest increase in fall and winter water due to increased precipitation. For the Sandy Basin, on the western slope of the Cascades, HL climate class does not change, but there are major changes in seasonality, especially for areas with low aquifer permeability, which experiences a $100 \%$ loss of spring seasonality. This would reduce summer baseflow, but effects could potentially be mitigated
\end{abstract}

by streamflow buffering effects provided by groundwater in the high aquifer permeability portions of the upper Sandy. The Middle Fork John Day Basin (MFJD), in northeastern Oregon, is snowmelt-dominated. The basin experiences a net loss of wet and moist climate area, along with an increase in dry climate area. The MFJD also experiences major shifts from spring to winter seasonality, representing a 20 $60 \%$ reduction in snowmelt-dominated area. Altered seasonality and/or magnitude of seasonal streamflows could potentially affect survival, growth and reproduction of salmonids in these watersheds, with the greatest effects projected for the MFJD. A major strength of the HL approach is that results can be applied to similarly classified, ungaged basins. Information resulting from such evaluations can help inform management responses to climate change at regional and basin scales without requiring detailed modeling efforts.

\section{Introduction}

Climate change is likely to have significant, long-term implications for freshwater resources. Changes in the amount and intensity of precipitation have been observed across much of the US (Groisman et al., 2005, 2012). Climate modeling experiments suggest these trends will continue throughout the 21 st century, with continued warming accompanied by a general intensification of the global hydrologic cycle 
(Intergovernmental Panel on Climate Change, 2007; Karl et al., 2009; Kharin et al., 2013). This calls into question the concept of "stationarity" that has provided the foundation for water management for decades (e.g., Milly et al., 2008).

Potential impacts of climate change include the transition of snow into rain, resulting in diminished snowpack and shifts in streamflow to earlier in the season (Service, 2004; Stewart et al., 2004, 2005; Barnett et al., 2005; Mote et al., 2005; Luce and Holden, 2009; Stewart, 2009; Mote and Salathé, 2010; Abatzoglou, 2011; Fritze et al., 2011; Johnson et al., 2012; Nolin, 2012; US EPA, 2013). Other possible impacts include changes in extreme high- and low-flow events, alteration of groundwater recharge rates, changes in the fate and transport of nutrients, sediments, and toxic chemicals, and shifts in important aquatic ecosystem processes and functions (Kundzewicz et al., 2007; Karl et al., 2009; Johnson et al., 2012; US EPA, 2013).

The impacts of these changes are expected to vary due to regional differences in meteorological forcing, physiographic setting and interaction with geology, local ecosystem processes, land use, and water management. In the western US, Fritze et al. (2011) found the timing of streamflow shifting towards earlier in the year in snowpack-dominated watersheds. In the US Pacific northwest (PNW), the transition from snow to rain is particularly relevant, because considerable portions of the snowpack accumulate close to the freezing point (Nolin and Daly, 2006). As a result, increases in air temperature can have dramatic effects on seasonal snow accumulation (Sproles et al., 2013) and subsequent contributions of snowmelt to baseflow. Luce and Holden (2009) found statistically significant declines in low-flow regimes from 1948 to 2006 in $72 \%$ of PNW study watersheds. This can have significant implications for human water needs, irrigation, drinking water and the summer habitat of aquatic biota during the driest portions of the year, when water demand is at its peak.

In the PNW, human demand for water, human land use within watersheds, and associated impacts on water quality can conflict with the needs of aquatic species, often with costly repercussions. For example, expenditures associated with river and stream restoration in the US exceed USD 1 billion annually (Bernhardt et al., 2005); with costs associated with the recovery of Pacific salmon in the Snake River basin alone projected to exceed USD 300 million annually (Huppert, 1999). Anticipated changes to streamflow and temperature regimes in the next century for PNW rivers and streams are of significant concern for the long-term viability of cold-water salmonids (Beechie et al., 2006; Battin et al., 2007; Mantua et al., 2010). The threatened and endangered status of many of these stocks under the Endangered Species Act often drive water and basin management in the region (McClure et al., 2013). Pacific salmon and trout life histories are cued by hydrologic and thermal regimes; and streamflow and temperature conditions during both winter and summer can strongly regulate survival and growth of salmon embryos and juveniles (Quinn, 2005). Winter flows can cause mortality of juvenile salmon due to displacement, injury, or exhaustion (Tschaplinski and Hartman, 1983), particularly during high-magnitude events that could increase under future climates (e.g., see US EPA, 2013). Increased synchrony of summer low flows and maximum temperatures (Arismendi et al., 2013) may increasingly stress salmonids under future climate change scenarios. Other low-flow stresses include increased competition for shrinking space (Chapman, 1966), reduced drift of macroinvertebrate prey and other food sources (Harvey et al., 2006), and increased incidence of disease and parasites (Cairns et al., 2005; McCullough et al., 2009) - all factors that can lead to reduced growth and survival of stream salmonids.

It is well understood that, while climate change is a global phenomenon, natural resource management responses to climate change (e.g., adaptation) are inherently local (Dozier, 2011). This refers both to the spatial scale and to the unique characteristics of a particular decision/management context. This situation presents an important challenge for informing management adaptation with scientific information about future climate risks, as such information is often nonlocal and somewhat generic. As a result, effort and additional analysis is often required to place the climate information in the context of the management endpoints of concern and other critical aspects of the particular decision or management need (Johnson and Weaver, 2009). In particular, there is an urgent need for translational science and science applications that can help practitioners frame their decisions contextually by supporting robust and decision-relevant climate change vulnerability evaluations (defined here as an evaluation of how a system will likely be altered by climate change). This would include information on likely changes in the timing and quantity of water resources, the effects of these changes on local watersheds, and possible consequences on local aquatic resources.

Context-specific tools and methods for vulnerability evaluation provide critical support for needed synthesis and translation at local to regional levels. One way to provide such information is to employ diagnostic approaches that use observation-based studies to analyze historical stream, snow, and climate data over multiple decades (e.g., Safeeq et al., 2013). A second approach is to use prognostic studies that integrate projected climate change into dynamic hydrologic models to better understand how these changes will be expressed hydrologically (Tague and Grant, 2009; Elsner et al., 2010; Surfleet et al., 2012).

While informative, both data- and model-based studies have deficiencies. Diagnostic studies are constrained by data limitations and, in the western US, are biased towards wetter areas (for example, see map at http://waterdata.usgs.gov/ or/nwis/rt). Prognostic studies can provide a more spatiallybalanced and deterministic understanding of climate impacts. However, they are commonly applied at broad geographic scales with poor spatial resolution, or focused on 


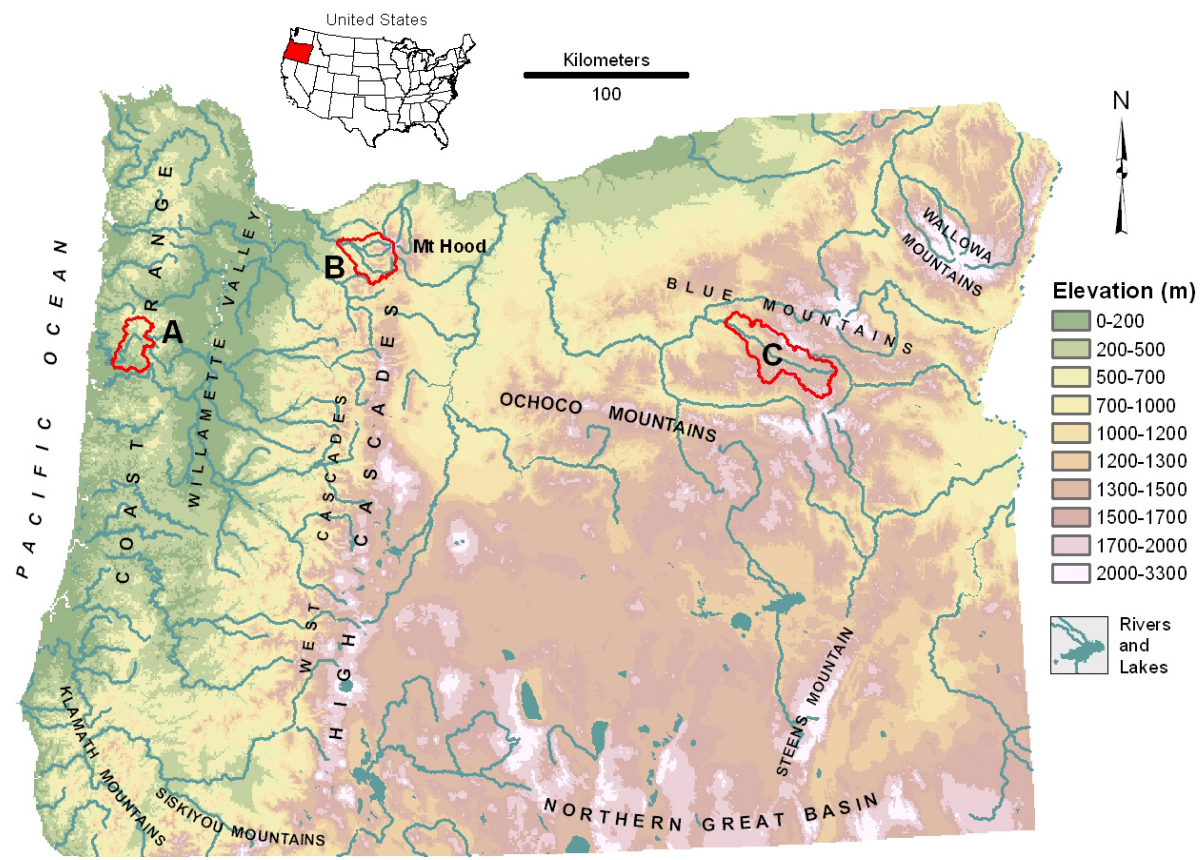

Figure 1. Elevation map of Oregon with major features and locations of three case study basins: (a) Siletz, (b) Sandy, (c) Middle Fork John Day.

gaged basins to allow for model validation (Sivapalan et al., 2003). Deficiencies in process understanding also constrain the quality of information that models can provide.

In contrast, a classification-based approach to assessing climate impacts on hydrologic systems could support a broad-scale analysis that provides a systematic understanding of how climate affects the hydrologic cycle across geographies (Sawicz et al., 2011; Safeeq et al., 2013); also see Savenije (2010) and Gao et al. (2014) for an alternative classification approach based on topography. In particular, the hydrologic landscape (HL) classification developed by Wigington et al. (2013) for the state of Oregon provides (a) integrated measures of the key drivers of the hydrologic characteristics of watersheds, and (b) an approach for coupling these drivers with information about potential future climate change to trace multiple, management-specific pathways of climate change impacts. Furthermore, the HL classification includes information on geology, which can influence hydrologic response to climate change (Tague et al., 2013). This contextualization of often hard-to-interpret climate information offers the possibility of more effectively supporting the needs of practitioners involved in the management of landscapes and watersheds in the face of both climate change and other stressors.

The purpose of this paper is twofold: first, we provide results from an analysis for the state of Oregon, using the HL classification and results from six future climate realizations to begin to understand the potential sensitivity of water resources to a range of possible future changes in climate. Results are presented statewide and for three case study basins representative of different regions across Oregon. The implications of these results for the magnitude and timing of water resources are discussed, as well as vulnerability of salmonids, which are an important water-dependent resource. Second, through the use of this case study we provide a proof-of-concept application of this approach to support climate-related decision-making, i.e., the integration of the HL approach with model-derived information about potential future climate change. This type of focused exploration can be leveraged to advance a broader dialogue about the need for, and lessons learned from, such approaches to inform management-relevant climate change vulnerability evaluations.

\section{Methods}

\subsection{Study area}

The state of Oregon, located in the Pacific northwestern US (Fig. 1), has diverse geologic and climatic conditions. Elevation ranges from sea level along the Pacific coast to over $3000 \mathrm{~m}$. The Cascade Mountains run north-south, dividing the state into western and central-eastern sections (Loy et al., 2001). The Western Cascades are comprised of highly weathered, low permeability bedrock, and the High Cascades have less weathered, higher permeability bedrock (Tague and Grant, 2004). The Coast Range is located adjacent to the Pacific Ocean and is comprised of sedimentary bedrock 
with intrusions of volcanic rock. The Willamette Valley, located between the Coast Range and Cascade Mountains, contains sedimentary and volcanic rocks overlain by flood deposits. Other major physiographic features include the Columbia Plateau in north-central Oregon, the Wallowa and Blue mountains in the northeast, the Northern Great Basin in the southeast, the Klamath and Siskiyou mountains to the southwest, and the Ochoco Mountains in the state's center. The Klamath, Siskiyou, and Blue mountains have extensive areas of metamorphic bedrock. Eastern Oregon bedrock is predominately volcanic in origin (Loy et al., 2001).

Westerly winds with moisture-laden marine air from the Pacific Ocean are the state's major source of precipitation. Oregon's mountain ranges produce orographic precipitation to their west and rain shadows to their east (Taylor and Hannan, 1999). The Cascades create a strong demarcation between the wet western third of the state and the dry eastern two-thirds (Fig. 1). Moisture conditions in western Oregon range from the moderately wet Willamette Valley (760$1520 \mathrm{~mm}$ average annual precipitation) to the wetter coastal areas $(1780-2290 \mathrm{~mm})$, and the very wet rain forests of the Coast Range (2540-5080 mm). In contrast, areas east of the Cascades are generally dry $(200-380 \mathrm{~mm})$ except at high elevations in the mountains. Temperatures west of the Cascades are generally mild and, on the coast, relatively uniform, whereas temperatures east of the Cascades are more extreme (Taylor and Hannan, 1999). In Oregon and elsewhere in the Pacific northwest, precipitation and temperature variability is influenced by ocean surface temperature fluctuations such as the El Niño-Southern Oscillation and the Pacific Decadal Oscillation (Fleming et al., 2007).

Precipitation follows a Mediterranean climate, with the greatest amounts during winter months. The abundance of winter precipitation results in the accumulation of a seasonal snowpack in the Cascades, with annual average depths ranging from 7620 to $13970 \mathrm{~mm}$ (Ruffner, 1985). There is less overall precipitation east of the Cascades, but snowfall can still be considerable in the higher elevations (Leibowitz et al., 2012). Although the Coast Range has the highest precipitation in the state, snowfall is relatively low overall (annual average of $25-76 \mathrm{~mm}$ ) because of its lower elevation. Snowfall in the Willamette Valley is not common.

Based on the 2001 National Land Cover Database (Homer et al., 2007; http://www.mrlc.gov), land use in western Oregon is predominately forested $(65 \%)$ and shrubland $(12 \%)$. Agricultural and developed areas account for 10 and $6 \%$ of western Oregon's land use, respectively, with the remaining $8 \%$ composed of herbaceous, wetlands, barren, and water land uses (in descending order). In eastern Oregon, shrubland dominates $(57 \%)$, followed by forest $(26 \%)$. Agricultural and developed land account for 7 and $1 \%$ of land cover, respectively, with the remaining $9 \%$ consisting of herbaceous, barren, wetland, and water land uses (in descending order).

\subsection{Initial 1971-2000 hydrologic landscape maps}

Wigington et al. (2013) developed an HL classification based, in part, on the works of Winter (2001) and Wolock et al. (2004). The Wigington et al. (2013) approach uses components of the climate-watershed system that control the magnitude, delivery, and movement of water into and through watersheds and stream networks. These components consist of five indices (Figs. S1-S2 in the Supplement): (1) annual climate, (2) climate seasonality, (3) aquifer permeability, (4) terrain, and (5) soil permeability. These indices were calculated for each of 5660 assessment units across Oregon (Fig. S3 in the Supplement). The assessment units were defined using drainage areas derived from a synthetic stream network with a $25 \mathrm{~km}^{2}$ minimum drainage area threshold. The resulting assessment units have an average area of $44 \mathrm{~km}^{2}$ and partition all of the drainage area for a given stream or river without the units being nested. Below, we review how the five HL indices were calculated (see Wigington et al., 2013, for further details).

The climate index is based on the Feddema (2005) moisture index (FMI), which was modified from Thornthwaite (1948). The FMI ranges from -1.0 (driest) to 1.0 (wettest), and is calculated as

$\mathrm{FMI}=\left\{\begin{array}{l}1-\frac{\mathrm{PET}}{P} \text { if } P \geq \mathrm{PET} \\ \frac{P}{\mathrm{PET}}-1 \text { if } P<\mathrm{PET},\end{array}\right.$

where $P$ and PET are mean annual precipitation and potential evapotranspiration (in $\mathrm{mm}$ ), respectively, and FMI is unitless. PET was calculated according to Hamon (1961) as a function of saturated water vapor density (a function of temperature, $T$, in ${ }^{\circ} \mathrm{C}$ ) and average day length. Annual mean $P$ and $T$ were based on 30-year (19712000) monthly normals, using $400 \mathrm{~m}$ PRISM (Parameterelevation Regressions on Independent Slopes Model) climate data (Daly et al., 2008). The climate index was then defined by assigning each assessment unit to the following Feddema moisture types: $F M I \geq 0.66=$ "V" (very wet); $0.66>\mathrm{FMI} \geq 0.33=$ "W" (wet); $0.33>$ FMI $\geq 0=$ "M" (moist); $0>$ FMI $\geq-0.33=$ "D" (dry); $-0.33>$ FMI $\geq-0.66=$ "S" (semiarid); and FMI $<-0.66$ $=$ "A" (arid).

For the seasonality index, monthly snowmelt modified surplus $\left(S^{\prime}\right.$, in $\left.\mathrm{mm}\right)$ was calculated for each assessment unit based on Leibowitz et al. (2012):

$$
\begin{aligned}
S_{\mathrm{m}}^{\prime} & =S_{\mathrm{m}}-\triangle \mathrm{PACK}_{\mathrm{m}}^{*}=\left(P_{\mathrm{m}}-\mathrm{PET}_{\mathrm{m}}\right) \\
& -\left(\mathrm{PACK}_{\mathrm{m}}^{*}-\mathrm{PACK}_{\mathrm{m}-1}^{*}\right),
\end{aligned}
$$

where $S_{\mathrm{m}}$ is monthly surplus (mm) and $\mathrm{PACK}_{\mathrm{m}}^{*}$ is a biascorrected, modeled snowpack value for month $m$ that is restricted to nonnegative values (Leibowitz et al., 2012). $S^{\prime}$ represents the amount of water available from atmospheric sources, taking into account potential evapotranspiration and snowpack/snowmelt, and is calculated as 30-year 
(1971-2000) monthly normals. If $\triangle \mathrm{PACK}_{\mathrm{m}}^{*}>0$, there is a net increase in snowpack (accumulation exceeds snowmelt), thereby reducing the amount of surplus water $\left(S_{\mathrm{m}}^{\prime}<S_{\mathrm{m}}\right)$. Conversely, if $\triangle \mathrm{PACK}_{\mathrm{m}}^{*}<0$, the net decrease in snowpack causes a net release of water (output exceeds any conversion of precipitation into snowpack). In this case $S_{\mathrm{m}}^{\prime}$ $>S_{\mathrm{m}}$. Finally, $S_{\mathrm{m}}^{\prime}$ was summed for each of four seasons: fall (October-December), winter (January-March), spring (April-June), and summer (July-September). The seasonality index was then defined by assigning to each assessment unit one of three classes (fall or winter, spring, or summer) based on the season with the maximum average accumulated $S^{\prime}$. Fall and winter seasons (hereafter referred to as winter) were combined because they encompass Oregon's normal Mediterranean wet season.

We created an aquifer permeability index to represent deep groundwater behavior in the assessment units, using maps by Gonthier (1984) and McFarland (1983). Based on the distributions of hydraulic conductivity values in the state, we created three aquifer permeability classes: (1) low permeability (median hydraulic conductivity $\leq 1.5 \mathrm{~m} \mathrm{day}^{-1}$ ), (2) moderate permeability (median hydraulic conductivity $>1.5$ and $\leq 3 \mathrm{~m} \mathrm{day}^{-1}$ ), and (3) high permeability (median hydraulic conductivity $>3 \mathrm{mday}^{-1}$ ). Our aquifer permeability index was defined by assigning each assessment unit the aquifer class with the highest percentage occurrence.

For our terrain index, we defined flatland (cells with $<1 \%$ slope) and relief (maximum elevation minus minimum elevation in the assessment unit), using a $30 \mathrm{~m}$ digital elevation model from the National Elevation Dataset (http://ned.usgs. gov). We then assigned assessment units to terrain classes according to the following criteria: (1) mountain: percentage of flatland $<10 \%$ and relief $>300 \mathrm{~m}$; (2) flat: percentage of flatland $>50 \%$; and (3) transitional: remaining units.

Soil permeability (defined within the top $10 \mathrm{~cm}$ of soil) was based on a $1 \mathrm{~km}$ cell size grid developed by the Pennsylvania State University Center for Environmental Informatics (http://www.cei.psu.edu). We averaged the permeability values for the upper two $5 \mathrm{~cm}$ soil layers. The percentage of cells within each soil permeability class (high: soil permeability $>8 \mathrm{~cm} \mathrm{~h}^{-1}$; moderate: soil permeability $>4$ and $\leq 8 \mathrm{~cm} \mathrm{~h}^{-1}$; and low: soil permeability $\leq 4 \mathrm{~cm} \mathrm{~h}^{-1}$ ) was calculated for each assessment unit. The class with the highest percentage in the assessment unit was then assigned as our soil permeability index.

\subsection{Simulated 2041-2070 hydrologic landscape maps}

We simulated future HL distributions under several distinct realizations of future climate change by recalculating the climate and seasonality indices, using mean monthly precipitation and temperature data produced by general circulation models (GCMs) for 2041-2070. This period was selected to represent potential mid-21st century changes. To do this, we used bias-corrected and statistically downscaled (BCSD) climate simulations (Maurer et al., 2007) drawn from the World Climate Research Programme's Coupled Model Intercomparison Project phase 3 (CMIP3; Meehl et al., 2007). BCSD provides simulation output for the period from 1950 to 2099. While BCSD results are available for a large number of GCMs, we limited our analysis to output from the European Centre HAMburg (ECHAM) and the Parallel Climate Model (PCM) GCMs. Given that this analysis is intended to serve as an initial proof-of-concept study, our intent was to bracket a large range of simulated changes in climate by including model/emission scenario combinations that were likely to produce both large and small relative changes from historical to mid-century time periods. This initial choice of the ECHAM and PCM models was motivated by the fact that these models demonstrated among the highest and lowest global climate sensitivities, respectively, to a doubling of $\mathrm{CO}_{2}$ across both equilibrium and transient climate sensitivity (Intergovernmental Panel on Climate Change, 2007). However, as will be discussed further, global climate sensitivity rank order does not necessarily hold at regional scales; see Figs. S4-S9 and S10-S15 in the Supplement for statewide trends in changes in monthly precipitation and temperature, respectively.

For each of the two GCMs, we processed simulations under three emissions scenarios drawn from the Intergovernmental Panel on Climate Change's (IPCC) Special Report on Emissions Scenarios (Nakićenović et al., 2000) for a total of six realizations of future climate. Each of these emissions scenarios is intended to describe plausible future developments in technology, society and the environment that ultimately correspond to distinct concentrations of greenhouse gases (GHGs). The A2 emissions scenario describes a heterogeneous future, with global per capita wealth and fertility rates converging very slowly, and technological advancement occurring more slowly and on a regional basis. In contrast, the A1b scenario describes a world of rapid economic growth with global population peaking mid-century as global per capita wealth converges. In this scenario global economies are balanced between fossil and nonfossil energy technologies. The B1 scenario assumes the same population pattern and global convergence as in A1b, but with a strong trend toward adoption of sustainable global solutions and resourceefficient technologies. The selection of these three scenarios provides future climate simulations that assume a relatively high (A2), medium (A1b), and low (B1) increase in global GHGs by the end of the 21st century. However, it is important to note that, for the mid-century time frame we consider in this paper, the $\mathrm{A} 1 \mathrm{~b}$ trajectory produces slightly higher GHG concentrations than does the A2 storyline (Nakićenović et al., 2000). Therefore, for the climate simulations we discuss here, the A1b experiments actually reflect greater GHG forcing than the $\mathrm{A} 2$ experiments.

A bilinear interpolation method was used to simultaneously project and resample $1 / 8^{\circ}$ climate data for the $2041-$ 2070 period for all six realizations. This allowed us to match 
Table 1. Attributes of the Siletz, Sandy, and Middle Fork John Day case study basins. Drainage area and $Q / S^{*}$ values from Wigington et al. (2013).

\begin{tabular}{lccccc}
\hline Stream & $\begin{array}{c}\text { USGS } \\
\text { site no. }\end{array}$ & $\begin{array}{c}\text { Drainage } \\
\text { area } \\
\left(\mathrm{km}^{2}\right)\end{array}$ & $Q / S^{*}$ & $\begin{array}{c}\text { Mean } \\
\text { elevation } \\
(\mathrm{m})\end{array}$ & $\begin{array}{c}\text { Relief } \\
(\mathrm{m})\end{array}$ \\
\hline Siletz & 14305500 & 523 & 1.07 & 400 & 1051 \\
Sandy & 14137000 & 681 & 0.96 & 1005 & 3161 \\
Middle Fork John Day & 14044000 & 1334 & 0.78 & 1455 & 1695 \\
\hline
\end{tabular}

the projection and $400 \mathrm{~m}$ grid cell size of the 1971-2000 $P$ and $T$ data used in the original HL classification. Output cell values of the interpolation were determined by weighting the values from the four nearest cell centers by the distance to the center of the output cell in the input grid. We calculated monthly climatologies for 2041-2070 as differences (deltas) from the 1971-2000 initial normals. Changes in precipitation were calculated as a percentage and changes in temperature were calculated in degrees Celsius. Average monthly precipitation values for 1971-2000 were then multiplied by the percent change deltas to produce simulated 2041-2070 average monthly precipitation values (Figs. S4-S9 in the Supplement). The maximum positive percentage of change in July precipitation (the month with the largest increases in precipitation) across the state ranged from 21 to $76 \%$ over the six realizations, while the minimum negative change ranged from -6 to $44 \%$. In December (the month with the greatest precipitation), the maximum positive and minimum negative changes were from 2 to 39 and -2 to $-9 \%$, respectively. For the 2041-2070 temperature values, the change deltas for monthly temperature were added to the 1971-2000 average monthly temperature values (Figs. S10-S15 in the Supplement). Temperature differences among the six realizations ranged from 0.9 to $1.5^{\circ} \mathrm{C}$ across the state. The $2041-2070$ $P$ and $T$ data were used to calculate projected future values of PET, FMI, and $S^{\prime}$. These were then used to update the climate and seasonality indices and produce projected HL maps for 2041-2070 (Figs. S16-S21 in the Supplement).

We examined maps showing changes between 1971-2000 and 2041-2070 in climate class, FMI, seasonality class, and $S^{\prime}$ by realization for our analysis, and examined trends in monthly $S^{\prime}$. We also produced confusion, or error, matrices (Congalton, 1991) to quantify changes in climate and seasonality class.

\subsection{Case study basins}

Wigington et al. (2013) noted that HL assessment units function as complete watersheds only for first-order ephemeral, intermittent, and small perennial streams; they do not serve as the sole water source for higher-order streams and rivers, which receive water from multiple assessment units. They found that HLs aggregated at the river basin scale can be used to estimate the integrated hydrologic conditions and behavior of higher-order streams and rivers. To do this, they introduced the term $S^{*}$ :

$S^{*}=\frac{\sum_{i=1}^{n}\left(A_{i} \times \max \left(S_{i}^{\prime}, 0\right)\right)}{\sum_{i=1}^{n} A_{i}}$,

where $S^{*}$ represents the area-weighted monthly watershed positive surplus from each of the $n$ assessment units in a basin, and $A_{i}$ is the area of assessment unit $i$. Deficits (negative $S^{\prime}$ values) were not included because it was hypothesized (Wigington et al., 2013) that local assessment units have the ability to contribute water to a mainstem river, but they do not have the ability to remove large amounts of water from the mainstem channel.

We calculated $S^{*}$ for three case study basins (Fig. 1): the Siletz and Sandy, in western Oregon, and the Middle Fork John Day in eastern Oregon. We compared these watershed positive surplus values with 30-year (1971-2000) mean monthly discharge $(Q$, in $\mathrm{mm})$, based on data from US Geological Survey gage stations (http://waterdata.usgs.gov.or/ nwis/dw). $S^{*}$ represents water directly available from rainfall or meltwater from snowpack (minus potential evapotranspiration) and serves as two major sources of stream runoff. It does not include changes in groundwater storage due to regional imports/exports, nor does it address lags of deep groundwater movement within basins. Based on the geology of a basin, $S^{*}$ and $Q$ could have very similar magnitudes and patterns or be very different (Wigington et al., 2013; Patil et al., 2014). Wigington et al. (2013) showed that $S^{*}$ and $Q$ could be used to interpret how a watershed's positive surplus and groundwater contribute to basin runoff. For example, Wigington et al. (2013) use the annual $Q / S^{*}$ ratio to assess whether a river experiences groundwater losses or gains: a $Q / S^{*}>1$ indicates that runoff is greater than the available surplus, and thus suggests groundwater imports (changes in annual storage are assumed to be zero since 30 -year normals are used). Conversely, a $Q / S^{*}<1$ suggests groundwater exports, since runoff is less than the available surplus. Characteristics of the three basins, including the $Q / S^{*}$ ratios, are provided in Table 1. 

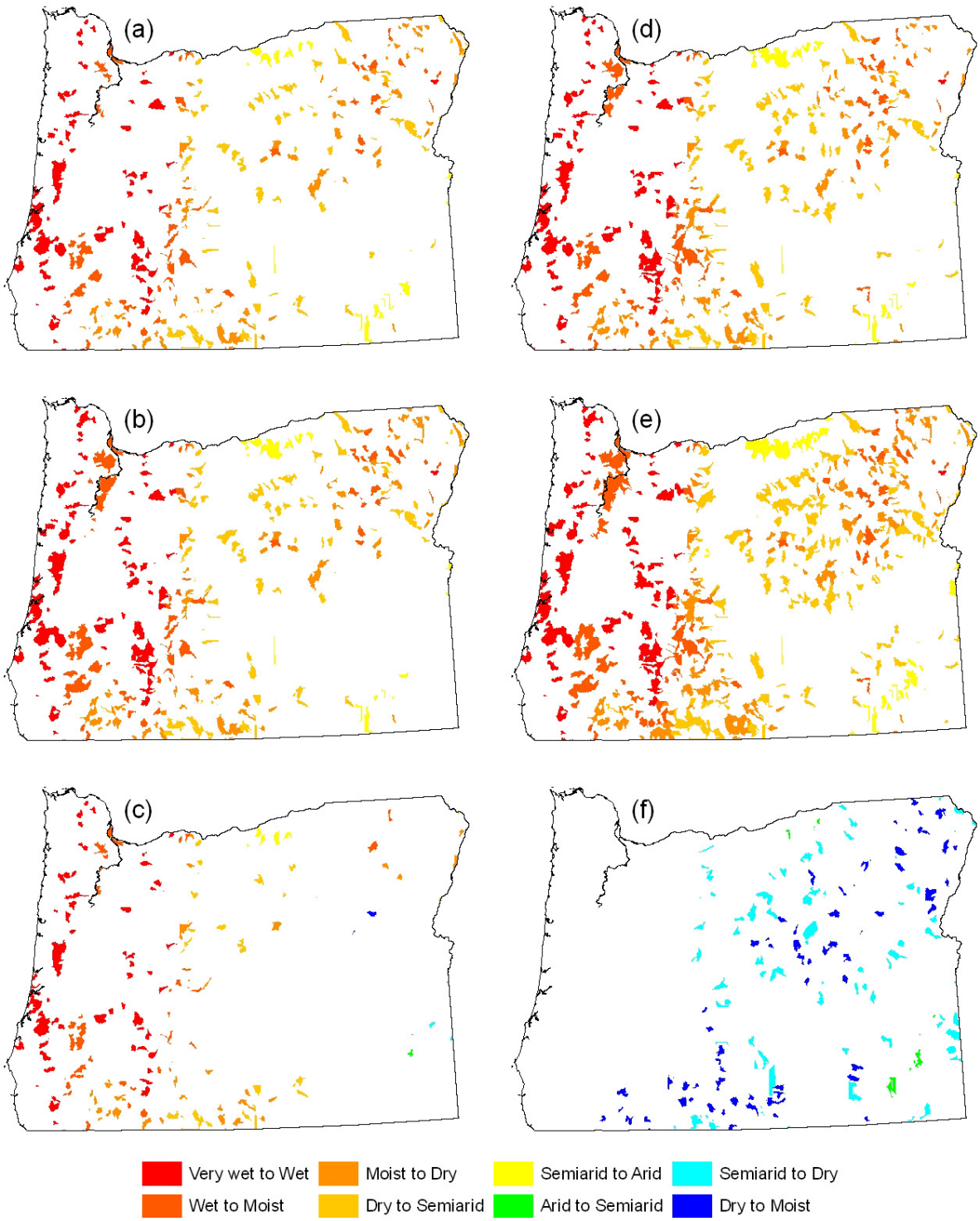

Figure 2. Change in climate class by realization (areas depicted in white did not experience changes in climate class): (a) ECHAM_A2, (b) ECHAM_A1b, (c) ECHAM_B1, (d) PCM_A2, (e) PCM_A1b, (f) PCM_B1.

\section{Results and discussion}

\subsection{Statewide}

\subsubsection{Climate class and Feddema moisture index}

Projected changes in climate class are distributed throughout Oregon under mid-21st century change realizations (Fig. 2). The percentage of assessment units that change class ranges from $4.4 \%$ for the ECHAM_B1 realization to $18.3 \%$ for PCM_A1b, with a mean of $10 \%$ over all six realizations (Table 2). Thus, climate class is expected to be stable for most assessment units. The distribution of units that change class is patchy and fairly evenly distributed across the state. However, two geographic areas experience no change for all six realizations: the southeastern portion of the Coast Range plus the adjacent portion of the southern Willamette Valley in western Oregon, and an arc-shaped region located between the Ochoco Mountains and Steens Mountain in southeastern Oregon (Figs. 1, 2).

For all but the two B1 realizations, changes are always to the next driest climate class. This can be seen by examining the confusion matrices (Table 3), where the diagonal represents assessment units that do not change and entries immediately above the diagonal are changes to the next drier class. Under the ECHAM_B1 realizations, changes are mostly to the next driest class, but there are also assessment units that switch to the next wetter class (i.e., changes immediately below the diagonal). For PCM_B1, all changes are to the next 

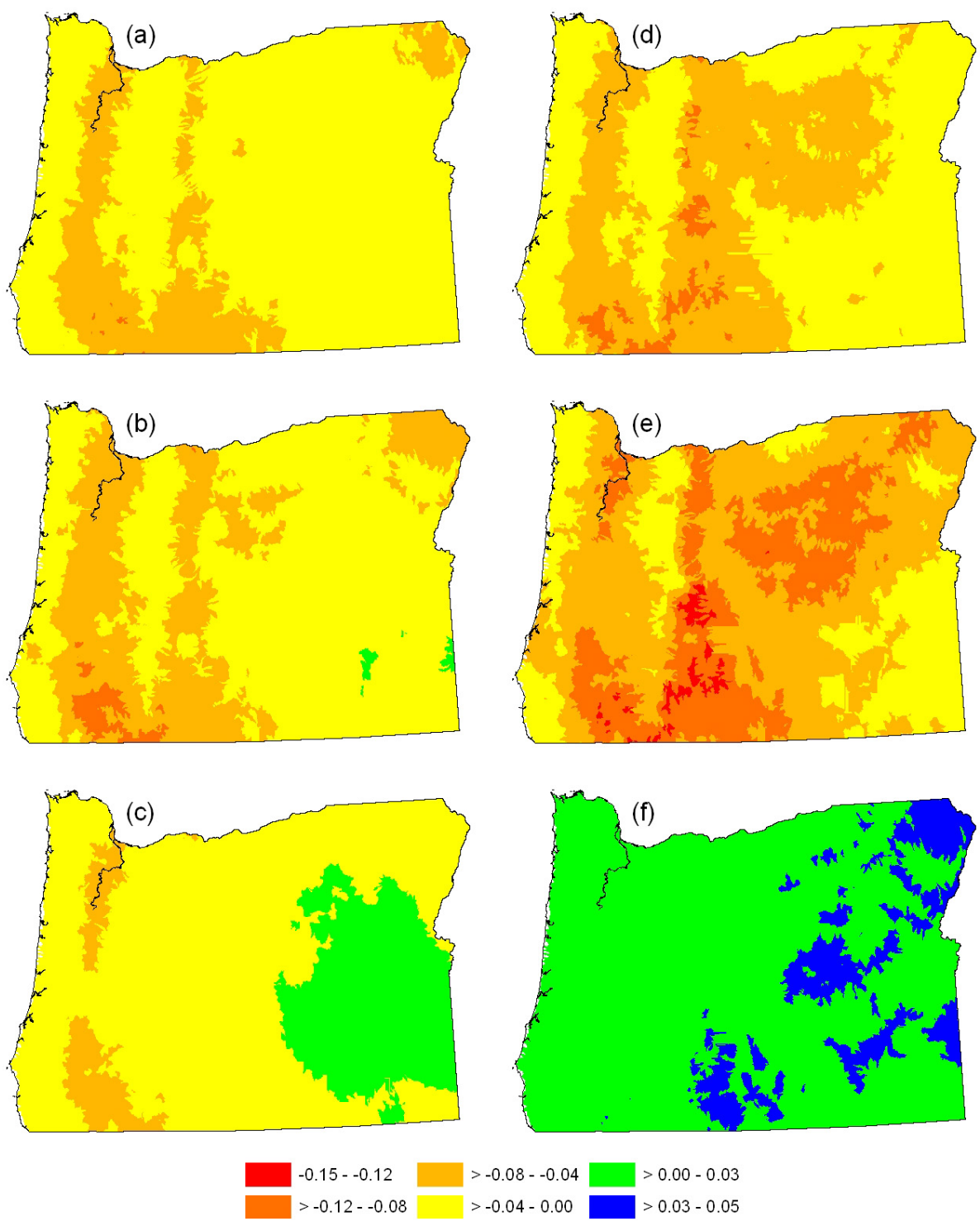

Figure 3. Change in Feddema moisture index (unitless) by realization: (a) ECHAM_A2, (b) ECHAM_A1b, (c) ECHAM_B1, (d) PCM_A2, (e) PCM_A1b, (f) PCM_B1.

wettest climate class. Change in climate class also varies by initial class: the mean change across all realizations ranges from a low of $2.7 \%$ for the semiarid class to a high of $17.5 \%$ for the very wet class (Table 2). However, the fact that the semiarid class is ranked lowest is influenced by the B1 realizations, both of which contain arid assessment units that change to semiarid. For all other four realizations there is no change in the arid class, since this is the driest class.

While trends for the discrete climate class are patchy across the state, changes in the continuous FMI are found in every assessment unit across the state (Fig. 3). For all realizations except PCM_B1, the FMI values predominately become more negative (i.e., drier). Changes in FMI are all positive (wetter) for PCM_B1, and positive changes also occur for the ECHAM_A1b and ECHAM_B1 realizations. For both the A2 and A1b emission scenarios, the PCM model produces more extreme (i.e., drier) changes in FMI than the ECHAM model. Note that this was contrary to our expectation, since the choice of PCM was intended to provide a lower climate sensitivity baseline - and presumably a smaller magnitude of simulated climate change - compared to the ECHAM model. This discrepancy highlights the potential differences between global and regional climate trends, even for the long-term (30-year) averages we consider here. Nevertheless, the use of both models in our analysis accomplishes the overall objective of bracketing a range of potential future climate change and investigating the resulting effect on HL characteristics. 

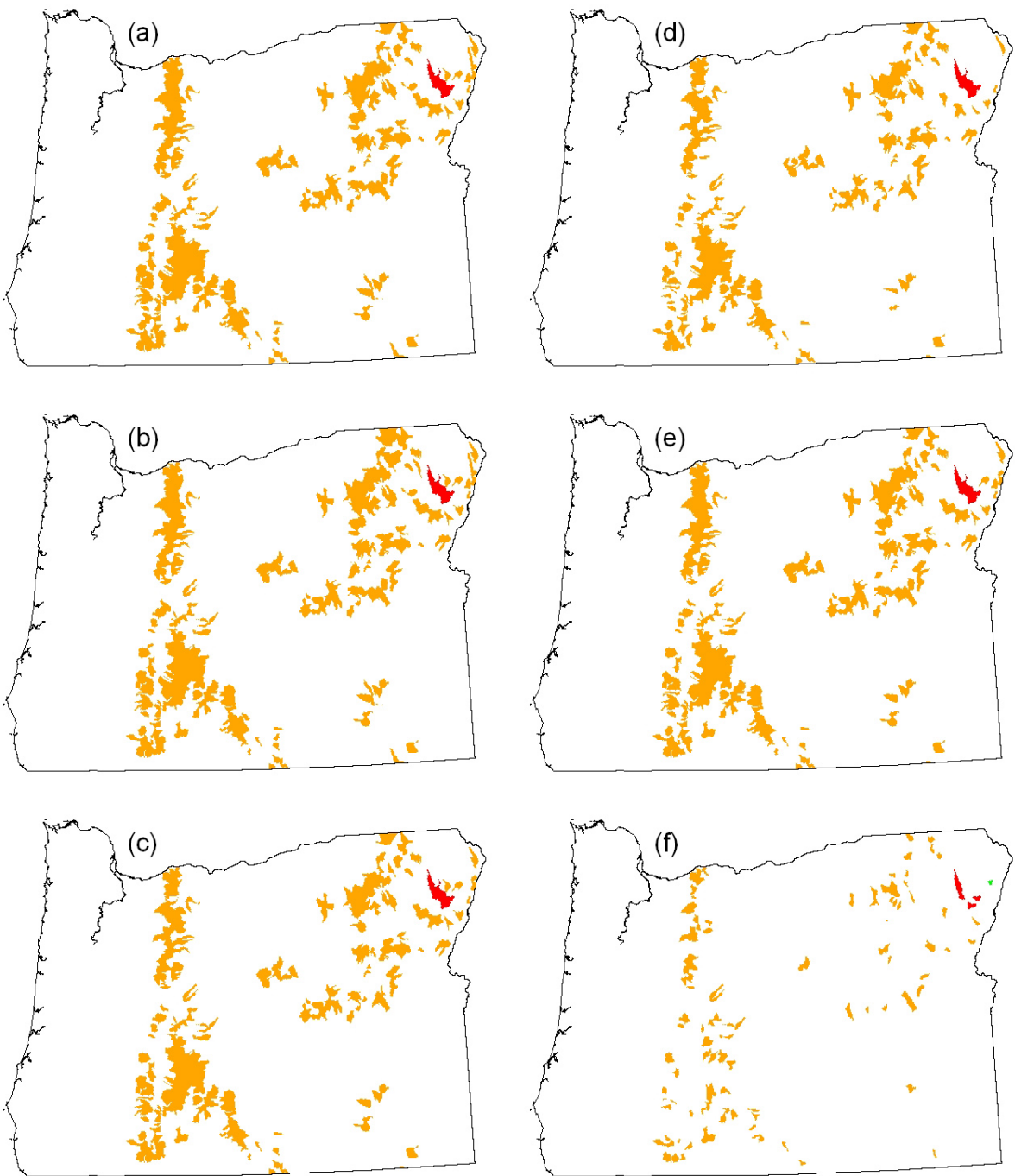

Summer to Spring

Spring to Fall-Winter

Fall-Winter to Spring

Figure 4. Change in seasonality class by realization (areas depicted in white did not experience changes in seasonality class): (a) ECHAM_A2, (b) ECHAM_A1b, (c) ECHAM_B1, (d) PCM_A2, (e) PCM_A1b, (f) PCM_B1.

Each assessment unit experiences some change in FMI under all six realizations. For the three ECHAM realizations and much of PCM_A2, most change is within the $>-0.04$ to 0.00 category (Fig. 3), which represents the smallest amount of drying. Even including PCM_B1, which gets wetter, absolute changes are predominately $<0.08$. These small magnitudes of change in FMI explain the patchiness of the change in climate class (Fig. 2), since each climate class has a large range in FMI (0.33) relative to the smaller changes that were simulated. For the PCM_A1b realization, many of the assessment units experience larger absolute changes in FMI and, as a result, this realization has the highest rate of climate class change ( $18.3 \%$; Table 2$)$ and a greater density of changed assessment units (Fig. 2).

\subsubsection{Seasonality class and surplus}

Changes in seasonality class (Fig. 4) have a much more limited geographic distribution, compared with changes in climate class. Seasonality changes are mostly restricted to the Cascade Range in western Oregon, the Blue and Wallowa mountains in northeastern Oregon, and the western portion of the Northern Great Basin. Overall, the percent of assessment units that change seasonality class ranges from $2.6 \%$ for PCM_B1 to $8.9 \%$ for ECHAM_A1b, with a mean of $7.3 \%$ over all six realizations (Table 2). However, these rates vary widely by initial seasonality class. For all realizations except PCM_B1, 0\% of the assessment units with winter seasonality change, and $100 \%$ of the units with summer seasonality change to spring seasonality. Also, there is a large 
Table 2. Proportion of assessment units that changed climate or seasonality class between initial (1971-2000) and simulated (2041-2070) conditions, by realization. Climate and seasonality for 2041-2070 based on simulated changes in precipitation and temperature. Climate classes: V - very wet, W - wet, M-moderate, D-dry, S-semiarid, A-arid. Seasonality classes: w - fall or winter, s-spring, u-summer.

\begin{tabular}{|c|c|c|c|c|c|c|c|c|}
\hline & & ECHAM_A2 & ECHAM_A1b & ECHAM_B1 & PCM_A2 & PCM_A1b & PCM_B1 & MEAN \\
\hline \multirow{7}{*}{$\begin{array}{l}\stackrel{\Xi}{\leftrightarrows} \\
\stackrel{\Xi}{\Xi}\end{array}$} & $\mathrm{V}$ & 0.175 & 0.236 & 0.140 & 0.219 & 0.281 & 0.000 & 0.175 \\
\hline & W & 0.094 & 0.148 & 0.047 & 0.136 & 0.208 & 0.028 & 0.110 \\
\hline & M & 0.161 & 0.182 & 0.060 & 0.213 & 0.324 & 0.070 & 0.168 \\
\hline & $\mathrm{D}$ & 0.123 & 0.138 & 0.037 & 0.160 & 0.277 & 0.085 & 0.137 \\
\hline & $\mathrm{S}$ & 0.018 & 0.017 & 0.005 & 0.023 & 0.042 & 0.057 & 0.027 \\
\hline & $\mathrm{A}$ & 0.000 & 0.000 & 0.049 & 0.000 & 0.000 & 0.222 & 0.045 \\
\hline & All & 0.090 & 0.113 & 0.044 & 0.119 & 0.183 & 0.053 & 0.100 \\
\hline \multirow{4}{*}{ 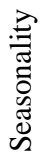 } & w & 0.000 & 0.000 & 0.000 & 0.000 & 0.000 & 0.000 & 0.000 \\
\hline & $\mathrm{s}$ & 0.673 & 0.684 & 0.619 & 0.568 & 0.643 & 0.197 & 0.564 \\
\hline & $\mathrm{u}$ & 1.000 & 1.000 & 1.000 & 1.000 & 1.000 & 0.429 & 0.905 \\
\hline & All & 0.087 & 0.089 & 0.080 & 0.074 & 0.083 & 0.026 & 0.073 \\
\hline
\end{tabular}

change to winter seasonality in assessment units that initially had spring seasonality, with a fairly uniform range from $56.8 \%$ (PCM_A2) to 68.4\% (ECHAM_A1b). The PCM_B1 seasonality change rates are clear outliers, when compared with the other five realizations: one of the assessment units with winter seasonality changes (although the rounded percent change is still $0.0 \%$ ), while the rates for summer and spring seasonality are 42.9 and $19.7 \%$, respectively. For all realizations, a change in seasonality is always to the next earlier season (i.e., spring to winter or summer to spring), except for the one winter assessment unit that changed under PCM_B1, which switched to spring seasonality (Table 4).

Results for all six realizations suggest large changes from spring and summer to winter seasonality. Based on the initial distribution of seasonality class, 4931 of the state's 5660 assessment units had winter seasonality (Table 4). Since seasonality is defined as the season with the maximum average accumulated $S^{\prime}$, and because $S^{\prime}$ excludes precipitation that goes into snowpack (Eq. 2), this means that $87.1 \%$ of these units are rain-dominated, with the other $12.9 \%$ being dominated by spring or summer snowmelt. Under PCM_B1 (Table 4), this distribution experiences a decline to $10.4 \%$ snowmelt-dominated units, representing a $19.3 \%$ reduction in the number of snowmelt-dominated units. Under the remaining five realizations, there is a much larger proportional change: $4.2-5.6 \%$ of the assessment units are projected to be snowmelt-dominated, representing a 56.2-67.8\% reduction in snowmelt-dominated units - including a complete loss of summer snowmelt units.

The simulated changes in seasonality (Tables 2, 4) can be explained by examining how $S^{\prime}$ changes over time. Figure 5a is a time series plot showing the median departures of projected $S^{\prime}$ values from the initial $S^{\prime}$ values for all assessment units. Through the fall and winter seasons (OctoberApril), departures are mostly positive; i.e., $S^{\prime}$ for projected conditions is greater than the initial $S^{\prime}$. Since $S^{\prime}$ excludes precipitation that goes into snowpack (Eq. 2), the increases in $S^{\prime}$ mean more precipitation is falling as rain, which generates more immediate surplus and less snowpack. In contrast, departures from initial $S^{\prime}$ values are mostly negative during the spring and summer months (April-September). Spring and summer precipitation in Oregon is low because of the Mediterranean climate. This means that the projected decreases in $S^{\prime}$ are due to reduced winter snowpacks and, subsequently, lower spring and summer snowmelt. However, there is no similar seasonal pattern with respect to percent departures of projected $S^{\prime}$ values (Fig. 5b). Note that a negative departure can have a positively valued percent departure if its denominator is negative (i.e., if 1971-2000 conditions during that month represent a deficit).

An example that further illustrates the monthly departure patterns is given in Fig. 6, which shows the spatial distribution in the change in monthly $S^{\prime}$ values for the ECHAM_A1b realization (see Figs. S22-S26 in the Supplement for results for the other five realizations). Increases in $S^{\prime}$ occur throughout most of the state from November to April, while decreases dominate from May to October. The areas experiencing the greatest declines in June and July $S^{\prime}$ are most of the high-elevation mountains, which have the greatest initial snowpack (Figs. 1, 6); this occurs because of simulated losses of snowpack and associated water storage. However, $S^{\prime}$ continues to increase in the Wallowa Mountains through June. These increases in fall and winter $S^{\prime}$, due to less snowpack, and subsequent decreases in spring and summer $S^{\prime}$, because of less snowmelt, cause the projected shifts from spring and summer to winter seasonality (Fig. 4; Tables 2, 4).

The overall effect of increased winter rain and decreased spring and summer snowmelt on water availability will depend, in part, on intrinsic watershed attributes, such as geology. In areas with low aquifer permeability and mountainous terrain, greater winter rains should generally result in increased discharge and possibly increased flood risk. 
(A)

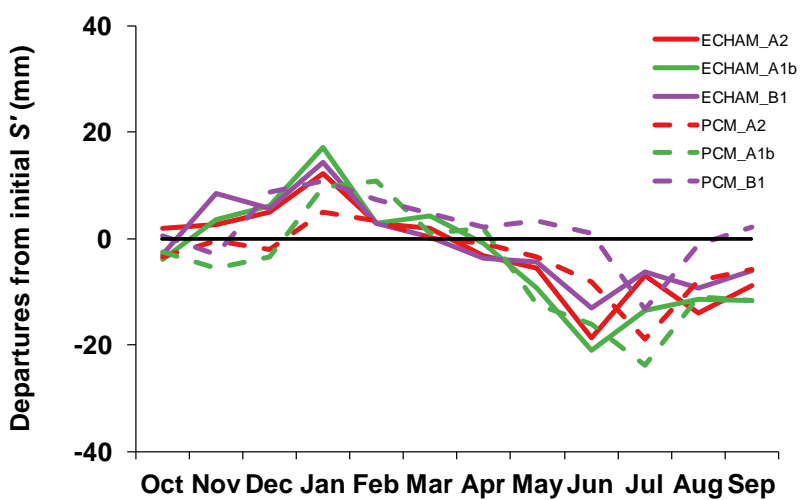

(B)

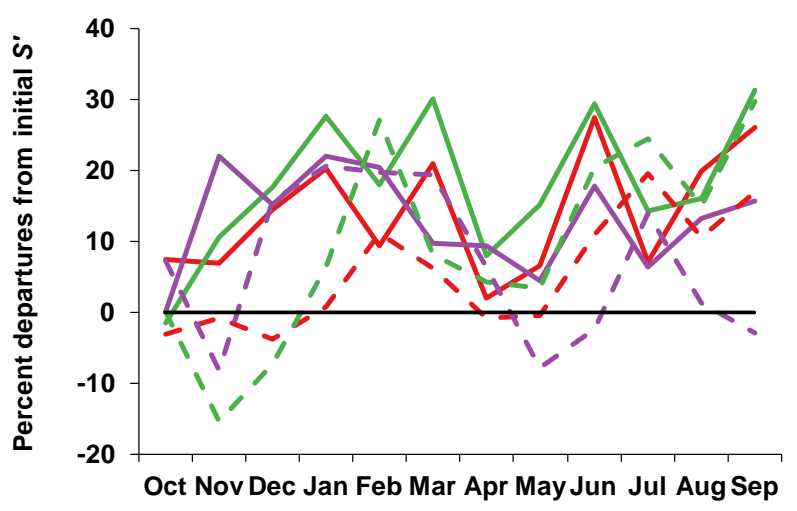

Figure 5. Median 2041-2070 departures (a) and percent departures (b) from initial monthly modified surplus $\left(S^{\prime}\right)$, by realization. Note: a total of six of the 5660 assessment units had an undefined percent departure for 1 month, due to divide by zeros. These values were set to zero when calculating the median percent departures. Also, note that a negative departure can have a positively valued percent departure if its denominator is negative (i.e., if 1971-2000 conditions during a month represent a deficit).

Summer baseflow in such areas should be reduced, leading to increased drought risk, due to the combination of less snowmelt and low aquifer discharge (resulting from the low aquifer permeability). Areas with high aquifer permeability should also have increased winter streamflow, though perhaps less so because some of the increased winter surplus will go towards groundwater recharge. Impacts to spring and summer baseflow should be mitigated in these high permeability areas by groundwater discharge. In the section below, we provide an overview of the patterns of projected hydrologic changes in select major regions across Oregon.

\subsubsection{Regional trends}

The mountainous portions of western Oregon (Western Cascades, Coast Range, Klamath Mountains; Fig. S27 in the Supplement), which include the Siletz case study basin, are rain-dominated (winter seasonality) with low permeability bedrock. All portions of watersheds in these areas have a water surplus that contributes to groundwater recharge and streamflow. Watersheds generally have relatively low internal water storage and water drains rapidly through watersheds and into streams, resulting in very low summer baseflows. For five of the six future realizations, these areas experience general drying (Figs. 3, 4) that should reduce winter streamflows and have relatively less influence on summer baseflows.

A large area of central Oregon and portions of western Oregon, including the Sandy case study basin, is composed of mountains (High Cascades, east flank Cascades, western portion of the Northern Great Basin; Fig. S27 in the Supplement) with large winter snowpacks and high permeability aquifers (Wigington et al., 2013). Water surplus increases with increasing elevations in these areas. Rapid infiltration of precipitation and meltwater, combined with deep aquifers, results in deep hydrologic flow paths and long residence times as water drains from assessment units to streams and rivers. Streams in these areas commonly have moderated streamflows with lower stormflow peaks and higher summer baseflows than other streams in Oregon (Wigington et al., 2013). For this region, results from all six realizations project a reduction in water surplus and a shifting of seasonality from spring to winter (transition from snowmelt-dominated systems to rainfall-dominated systems) in numerous assessment units, particularly at lower elevations. Over time, reductions in water surplus will result in concomitant reductions in streamflows, although these reductions may be experienced downstream of individual assessment units (Wigington et al., 2013). The influence of the shift from snow-dominated assessment units to rain-dominated assessment units will likely result in some reduction in summer baseflow, but this effect will be much smaller (in relative terms) than assessment units with low aquifer permeability and associated low internal storage.

Throughout the remainder of the Northern Great Basin and the Blue Mountains of eastern Oregon (Fig. S27 in the Supplement), including the Middle Fork John Day case study basin, mountains occupy small portions of river basins; however, they are critical sources of water for these basins. Winter snowpacks develop in the mid and high elevations and supply water for human uses and rivers via snowmelt in the spring. The valleys and lowlands are typically semiarid or arid and have annual water deficits. Eastern Oregon assessment units generally have a mixture of moderate and low permeability aquifers. If a low permeability aquifer is present, internal watershed storage is low and water moves rapidly to streams as snowmelt occurs; summer baseflows are supported primarily through the release of meltwater. In assessment units with moderate permeability aquifers, snowmelt waters have the opportunity to percolate into the aquifers and be released to streams more slowly, resulting in higher summer baseflows (Wigington et al., 2013). 
Table 3. Confusion matrices for initial (1971-2000) vs. simulated (2041-2070) climate class by realization. Entries are numbers of assessment units. Parenthetical number is the proportion of the initial climate class represented in the projected climate class (cell value divided by row total; values sum to 1 by row). Diagonal entries shown in bold. Entries to the right of the diagonal represent changes to drier conditions, while entries to the left represent wetter conditions. Climate classes: V-very wet, W-wet, M-moderate, D-dry, S-semiarid, A-arid.

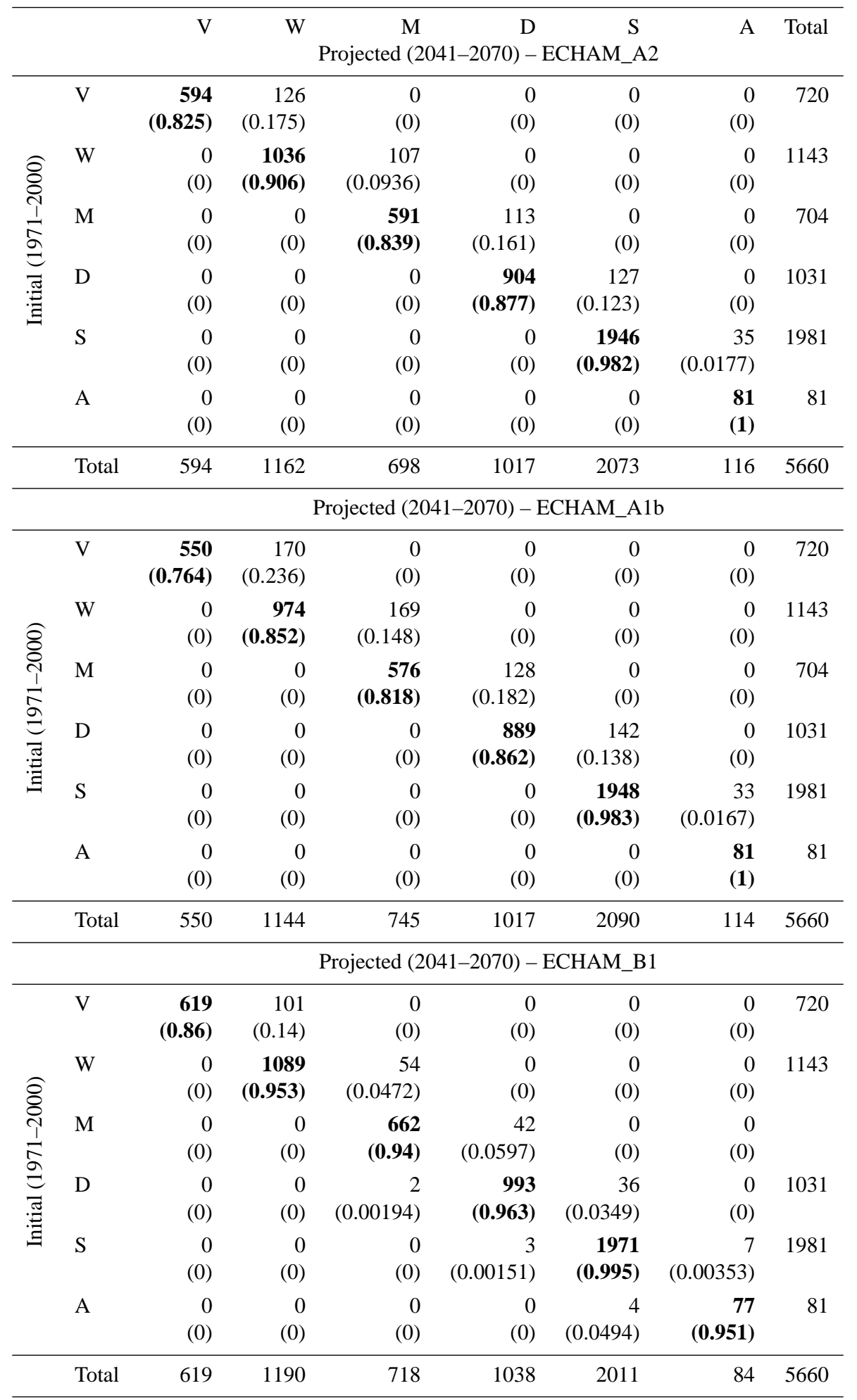


Table 3. Continued.

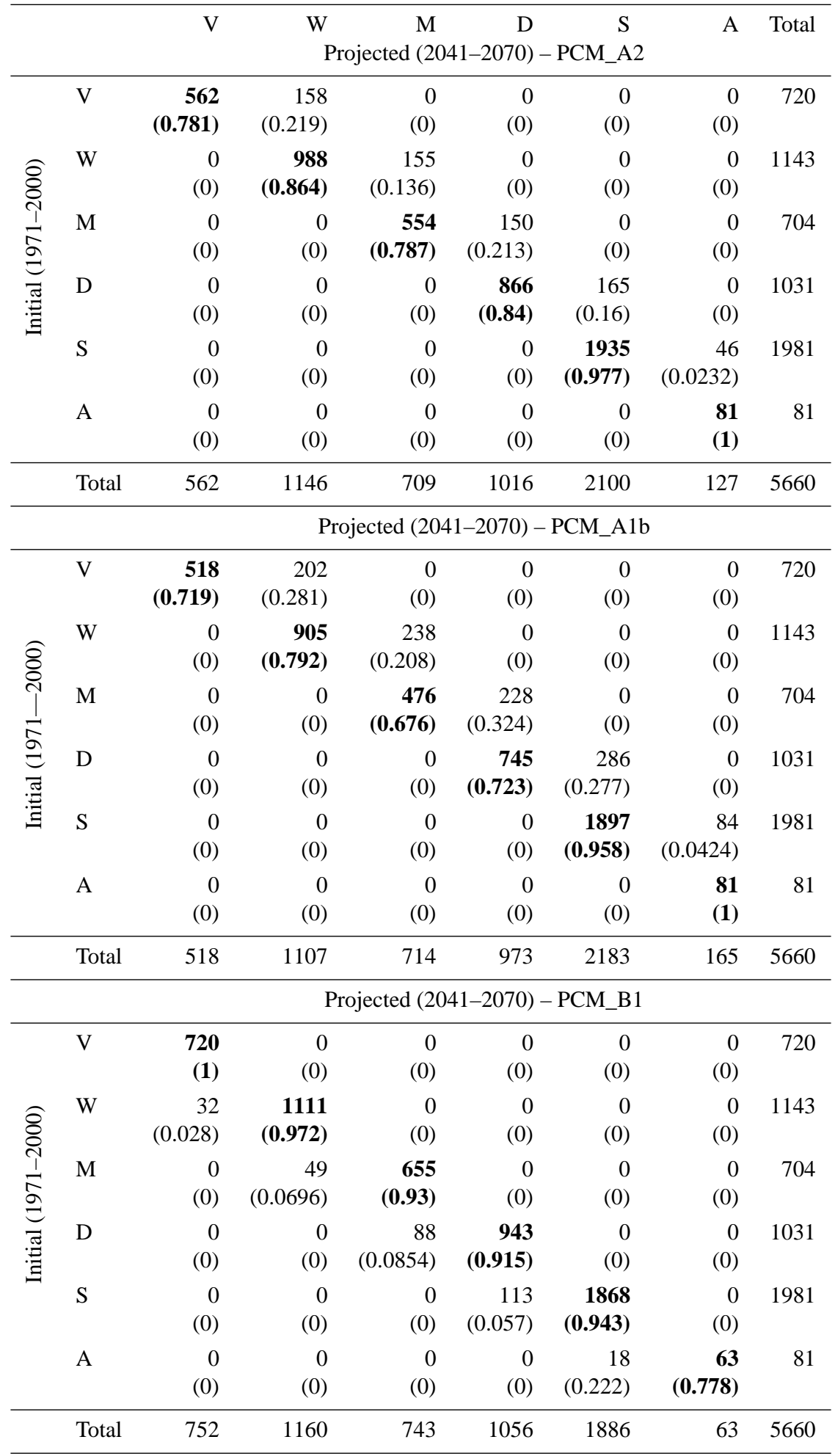


Table 4. Confusion matrices for initial (1971-2000) vs. projected (2041-2070) seasonality class by realization. Entries are numbers of assessment units. Parenthetical number is the proportion of the initial seasonality class represented in the projected seasonality class (cell value divided by row total; values sum to 1 by row). Diagonal entries shown in bold. Seasonality classes: $w$ - fall or winter, $\mathrm{s}$-spring, $\mathrm{u}$-summer.

\begin{tabular}{|c|c|c|c|c|c|}
\hline & & w & $\mathrm{s}$ & $\mathrm{u}$ & Total \\
\hline & & \multicolumn{4}{|c|}{ Projected (2041-2070) - ECHAM_A2 } \\
\hline \multirow{6}{*}{ 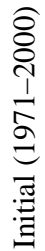 } & \multirow[t]{2}{*}{$\mathrm{w}$} & 4931 & 0 & 0 & \multirow[t]{2}{*}{4931} \\
\hline & & (1) & $(0)$ & $(0)$ & \\
\hline & \multirow[t]{2}{*}{$\mathrm{s}$} & 486 & 236 & 0 & \multirow[t]{2}{*}{722} \\
\hline & & $(0.673)$ & $(0.327)$ & $(0)$ & \\
\hline & \multirow[t]{2}{*}{$\mathrm{u}$} & 0 & 7 & 0 & \multirow[t]{2}{*}{7} \\
\hline & & (0) & (1) & (0) & \\
\hline & \multirow[t]{2}{*}{ Total } & 5417 & 243 & 0 & 5660 \\
\hline & & \multicolumn{4}{|c|}{ Projected (2041-2070) - ECHAM_A1b } \\
\hline \multirow{6}{*}{ 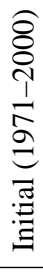 } & \multirow[t]{2}{*}{$\mathrm{w}$} & 4931 & 0 & 0 & \multirow[t]{2}{*}{4931} \\
\hline & & (1) & $(0)$ & (0) & \\
\hline & \multirow[t]{2}{*}{ s } & 494 & 228 & 0 & \multirow[t]{2}{*}{722} \\
\hline & & $(0.684)$ & $(0.316)$ & (0) & \\
\hline & \multirow[t]{2}{*}{$\mathrm{u}$} & 0 & 7 & $\mathbf{0}$ & \multirow[t]{2}{*}{7} \\
\hline & & $(0)$ & (1) & (0) & \\
\hline & \multirow[t]{2}{*}{ Total } & 5425 & 235 & 0 & 5660 \\
\hline & & \multicolumn{4}{|c|}{ Projected (2041-2070) - ECHAM_B1 } \\
\hline \multirow{6}{*}{ 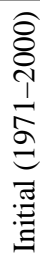 } & $\mathrm{w}$ & 4931 & 0 & 0 & \multirow[t]{2}{*}{4931} \\
\hline & (1) & $(0)$ & (0) & & \\
\hline & \multirow[t]{2}{*}{ s } & 447 & 275 & 0 & \multirow[t]{2}{*}{722} \\
\hline & & $(0.619)$ & (0.381) & (0) & \\
\hline & \multirow[t]{2}{*}{$\mathrm{u}$} & 0 & 7 & 0 & \multirow[t]{2}{*}{7} \\
\hline & & (0) & (1) & (0) & \\
\hline & \multirow[t]{2}{*}{ Total } & 5378 & 282 & 0 & 5660 \\
\hline & & \multicolumn{4}{|c|}{ Projected (2041-2070) - PCM_A2 } \\
\hline \multirow{7}{*}{ 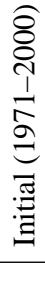 } & \multirow[t]{2}{*}{$\mathrm{w}$} & 4931 & 0 & 0 & \multirow[t]{2}{*}{4931} \\
\hline & & (1) & $(0)$ & (0) & \\
\hline & $\mathrm{s}$ & 410 & 312 & 0 & 722 \\
\hline & & (0.568) & $(\mathbf{0 . 4 3 2})$ & (0) & \\
\hline & $\mathrm{u}$ & 0 & 7 & $\mathbf{0}$ & 7 \\
\hline & & (0) & (1) & (0) & \\
\hline & Total & 5341 & 319 & 0 & 5660 \\
\hline
\end{tabular}

Throughout eastern Oregon, assessment units are projected to have lower water surplus values on an annual basis and to shift seasonality from spring (snowmelt-dominated) to winter (rain-dominated). Assessment units with low permeability aquifers will have little internal water storage to moderate the influence of snowpack loss, whereas assessment units
Table 4. Continued.

\begin{tabular}{|c|c|c|c|c|c|}
\hline & & \multicolumn{4}{|c|}{ Projected (2041-2070) - PCM_A1b } \\
\hline \multirow{3}{*}{ 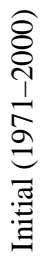 } & $\mathrm{w}$ & $\begin{array}{r}4931 \\
(1)\end{array}$ & $\begin{array}{r}0 \\
(0)\end{array}$ & $\begin{array}{r}0 \\
(0)\end{array}$ & 4931 \\
\hline & $\mathrm{s}$ & $\begin{array}{r}464 \\
(0.643)\end{array}$ & $\begin{array}{r}258 \\
(0.357)\end{array}$ & $\begin{array}{r}0 \\
(0)\end{array}$ & 722 \\
\hline & $\mathrm{u}$ & $\begin{array}{r}0 \\
(0)\end{array}$ & $\begin{array}{r}7 \\
(1)\end{array}$ & $\begin{array}{r}\mathbf{0} \\
(\mathbf{0})\end{array}$ & 7 \\
\hline & Total & 5395 & 265 & 0 & 5660 \\
\hline \multirow{5}{*}{ 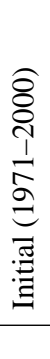 } & & \multicolumn{4}{|c|}{ Projected (2041-2070) - PCM_B1 } \\
\hline & $\mathrm{w}$ & $\begin{array}{r}4930 \\
(1)\end{array}$ & $\begin{array}{r}1 \\
(0.000203)\end{array}$ & $\begin{array}{r}0 \\
(0)\end{array}$ & 4931 \\
\hline & $\mathrm{s}$ & $\begin{array}{r}142 \\
(0.197)\end{array}$ & $\begin{array}{r}580 \\
(0.803)\end{array}$ & $\begin{array}{r}0 \\
(0)\end{array}$ & 722 \\
\hline & $\mathrm{u}$ & $\begin{array}{r}0 \\
(0)\end{array}$ & $\begin{array}{r}3 \\
(0.429)\end{array}$ & $\begin{array}{r}4 \\
(0.571)\end{array}$ & 7 \\
\hline & Total & 5072 & 584 & 4 & 5660 \\
\hline
\end{tabular}

with moderate aquifer permeability will be able to store some winter precipitation and release it as summer baseflow.

Special mention should be made of the Wallowa Mountains in eastern Oregon (Fig. S27 in the Supplement). The Wallowas, along with the High Cascades, have the highest accumulation of snowpack in the state, and are projected to have the smallest relative changes in our six modeling realizations. However, they do experience changes, in which some high-elevation assessment units shift from summer (late snowmelt that sustains summer baseflow) to spring seasonality.

\subsection{Case study basins}

\subsubsection{Siletz River basin}

The Siletz River basin (Fig. 1a; Table 1) is in the Oregon Coast Range, and occurs in the first region we described (mountainous portions of western Oregon; Fig. S27 in the Supplement). The Siletz is fairly uniform in HL composition (Fig. 7a), initially having only three classes, and with the same climate, seasonality, and aquifer permeability (Table 5). All of the basin's assessment units have very wet climate, winter seasonality, and low aquifer permeability, and they are dominated by mountainous terrain and low to moderate soil permeability. As a result, each assessment unit makes similar contributions to the basin's hydrologic function on an areal basis. Because of climate and geologic controls, the timing and magnitudes of $Q$ and watershed positive surplus $\left(S^{*}\right)$ are very similar in this basin (Fig. 7b): low infiltration, limited groundwater storage, and a steep dissected landscape result in a fast system that responds quickly to the high winter 

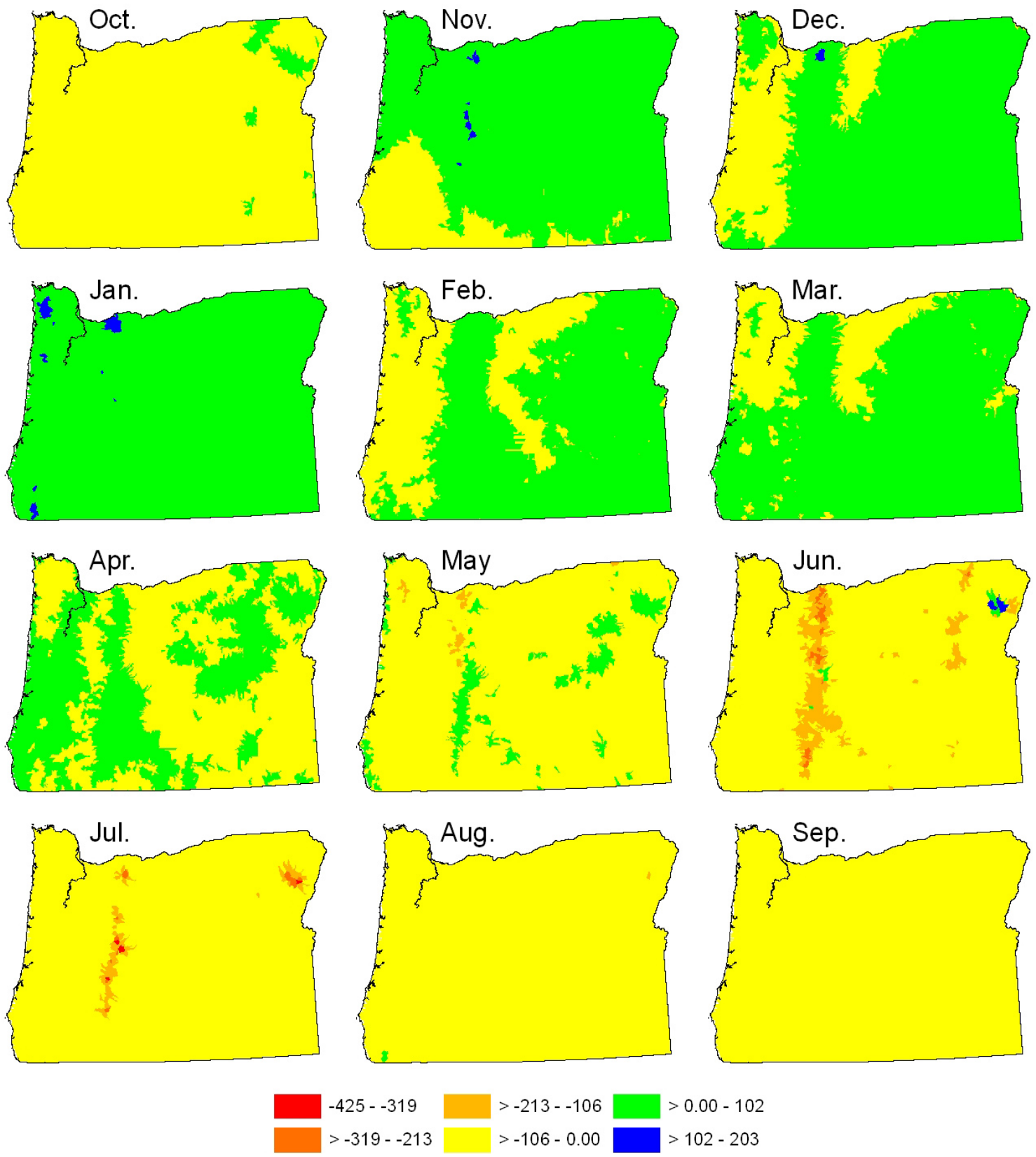

Figure 6. Change in monthly modified surplus $\left(\Delta S^{\prime}\right.$, in mm) for the ECHAM_A1b realization.

rain delivery. As a result of these combined factors, the Siletz peak discharge is the highest of the three case study basins (Figs. 7-9). $Q$ slightly lags $S^{*}$ during the fall rising period, suggesting that this represents the time needed for soil pore space to fill. This is balanced by a lag in the declines that occur due to reduced precipitation and increased PET during spring and summer, suggesting some minimal residual baseflow from storage. Once soil saturation occurs in December (the wettest month), water moves rapidly through the system, and water held within the subsurface is transitioned into streamflow. However, $Q$ is somewhat higher than $S^{*}$ during this winter period, possibly suggesting minimal groundwater imports, in spite of low aquifer permeability. Further evidence of this is a $Q / S^{*}$ ratio of 1.07 (Table 1), suggesting that the basin receives small amounts of groundwater inputs. Alternatively, our potential evapotranspiration value may be overestimating actual evapotranspiration.

The impacts of projected climate change are relatively straightforward in the Siletz and similar rain-dominated systems. In terms of class distribution, a small change is expected from some of the very wet $(\mathrm{V})$ to wet $(\mathrm{W})$ climate units, with no change in seasonality (Table 5). The effects 

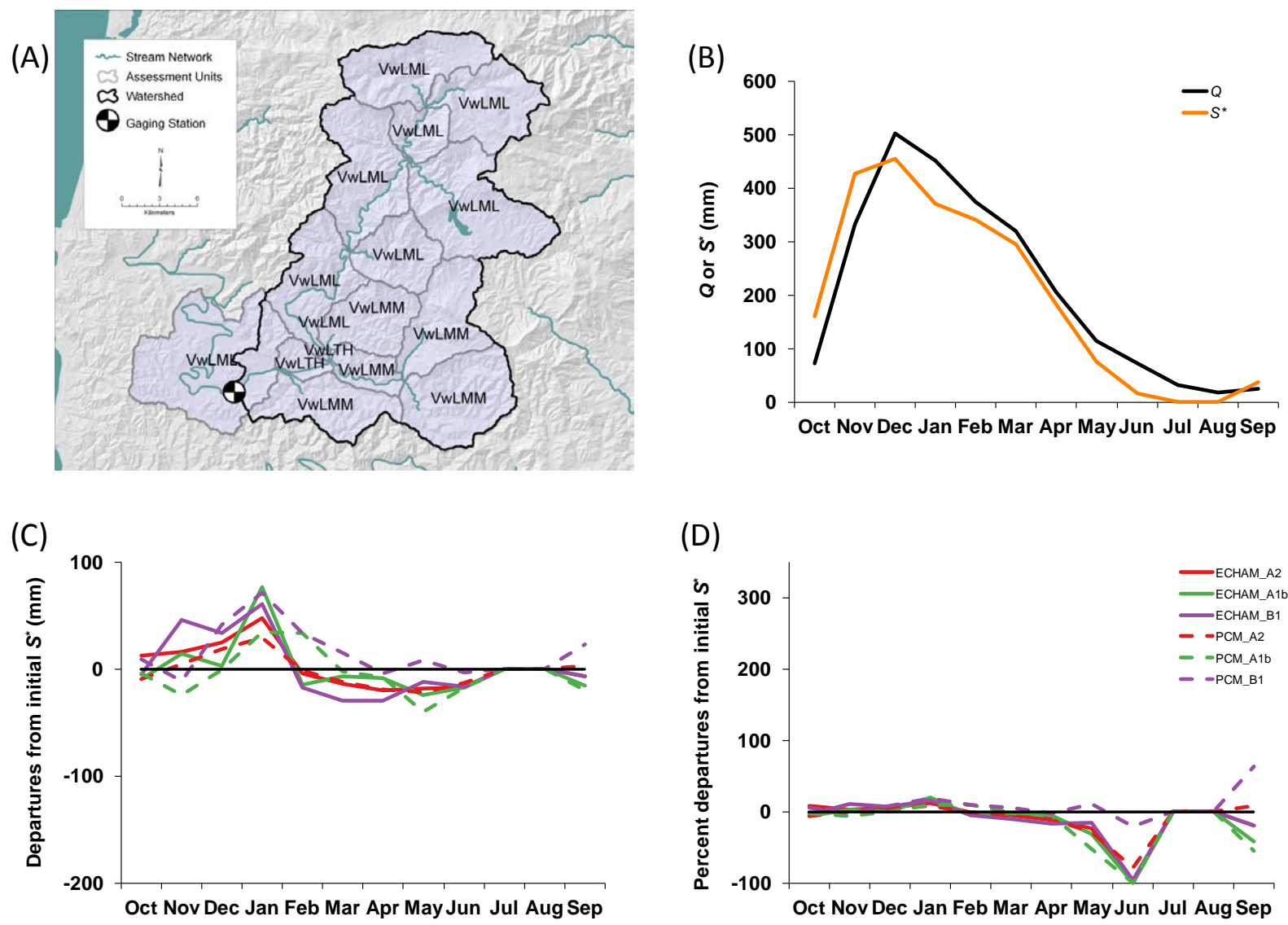

Figure 7. Results for the Siletz River basin, Oregon. (a) Initial (1971-2000) HL distribution; (b) comparison of initial mean monthly discharge $(Q$, in $\mathrm{mm})$ and watershed positive surplus $\left(S^{*}\right.$, in $\left.\mathrm{mm}\right)$; (c) 2041-2070 departures from initial monthly $S^{*}$, by realization; and (d) 2041-2070 percent departures from initial monthly $S^{*}$, by realization (July and August values undefined due to division by zeros).

are largest under the PCM_A1b realization: $12.2 \%$ of the area is projected to have wet climate, compared to $0.0-4.9 \%$ for the other five realizations. This would suggest minimal impacts to the basin. In spite of these switches to drier climate, $S^{*}$ increases during the fall and winter in all six realizations due to increased precipitation (Fig. 7c). The largest of these increases in $S^{*}$ is seen in January, with an equivalent increase from 29.6 (PCM_A2) to 77.1 mm (ECHAM_A1b). Proportionally, however, these increases are relatively small (Fig. 7d), ranging from 8.0 to $20.8 \%$. Shifts to the drier climate class occur because gains in fall and water $S^{*}$ are offset by losses during the spring and summer. $S^{*}$ values are reduced during the spring and summer months because of increased PET from warmer temperatures. The largest proportional effects occur in June (Fig. 7d), where $100 \%$ loss is experienced under three of the realizations, and all but PCM_B1 $(-20.6 \%)$ experience a loss of at least $78 \%$.

Because the Siletz Basin is groundwater-limited and hydrologically responsive, it can be inferred that changes in $S^{*}$ will be directly expressed in streamflow. As a result, increased precipitation during the winter months could potentially cause monthly streamflow increases of up to $19 \%$.
During spring and summer, there could potentially be a complete reduction in contributions of modified surplus (i.e., $S^{*}$ ) to mean monthly runoff. Spring and summer runoff will probably continue in the Siletz, because of the limited groundwater contributions. However, any reductions in groundwater imports could further reduce spring and summer discharge.

Changes in flow that result from climate change could have implications for water-dependent uses within the Siletz. Irrigation, industrial, and municipal use of water in the Siletz and similar Coast Range basins is minimal, although such use can be locally important, especially to towns along the coast. These river systems provide critical habitat for salmonids, including the threatened coho salmon (Oncorhynchus kisutch) (Stout et al., 2012). Modified streamflow and temperature regimes, human-caused habitat modifications, and largescale changes to ocean conditions and marine productivity are factors implicated in declines of this species in the Oregon Coast Range (Stout et al., 2012). In an evaluation of potential climate sensitivity, Stout et al. (2012) concluded that reduced summer streamflows and elevated water temperatures would reduce available rearing habitat for coho salmon 
Table 5. HL composition (percentage of area) of three case study basins for initial (1971-2000) conditions and projected (2041-2070) realizations. The five letter HL class represents codes for climate (V - very wet, W - wet, M-moist, D-dry, S - semiarid, A - arid), seasonality ( $\mathrm{w}$-fall or winter, $\mathrm{s}$-spring, $\mathrm{u}$-summer), aquifer permeability $(\mathrm{H}$-high, $\mathrm{M}$-moderate, $\mathrm{L}-\mathrm{low})$, terrain $(\mathrm{M}$ - mountain, $\mathrm{T}$-transitional, $\mathrm{F}$ - flat), and soil permeability ( $\mathrm{H}$ - high, $\mathrm{M}$ - moderate, $\mathrm{L}$-low), respectively.

\begin{tabular}{|c|c|c|c|c|c|c|c|}
\hline HL class & $1971-2000$ & ECHAM_A2 & ECHAM_A1b & ECHAM_B1 & PCM_A2 & PCM_A1b & PCM_B1 \\
\hline \multicolumn{8}{|c|}{ Siletz River } \\
\hline VwLML & 63.25 & 63.25 & 63.25 & 63.25 & 63.25 & 63.25 & 63.25 \\
\hline VwLMM & 34.81 & 31.83 & 31.83 & 31.83 & 31.83 & 24.57 & 34.81 \\
\hline VwLTH & 1.94 & 1.81 & - & 1.81 & - & - & 1.94 \\
\hline WwLMM & - & 2.97 & 2.97 & 2.97 & 2.97 & 10.23 & - \\
\hline WwLTH & - & 0.13 & 1.94 & 0.13 & 1.94 & 1.94 & - \\
\hline \multicolumn{8}{|c|}{ Sandy River } \\
\hline VwHMM & 3.99 & 73.77 & 73.77 & 48.18 & 48.18 & 73.77 & 17.73 \\
\hline VwLML & 9.33 & 9.33 & 9.33 & 9.33 & 9.33 & 9.33 & 9.33 \\
\hline VwLMM & 12.11 & 16.90 & 16.90 & 16.90 & 16.90 & 16.90 & 16.90 \\
\hline VsHMM & 69.78 & - & - & 25.59 & 25.59 & - & 56.04 \\
\hline VsLMM & 4.79 & - & - & - & - & - & - \\
\hline \multicolumn{8}{|c|}{ Middle Fork John Day River } \\
\hline WsLML & 4.42 & 2.22 & 2.22 & 2.22 & - & - & 2.22 \\
\hline WsLMM & - & - & - & - & - & - & 2.28 \\
\hline WsMML & 2.16 & - & - & 3.48 & - & - & 3.48 \\
\hline WsMMM & 3.39 & - & - & 3.37 & - & - & 3.37 \\
\hline MwLMM & 0.28 & 15.90 & 15.90 & 24.36 & 11.38 & 8.25 & 16.11 \\
\hline MwMMM & 8.25 & 15.08 & 15.08 & 10.12 & 5.58 & 15.08 & 4.54 \\
\hline MwMTM & - & 0.28 & 0.25 & 0.28 & 0.25 & - & - \\
\hline MsLML & - & - & - & - & 2.22 & 2.22 & - \\
\hline MsLMM & 4.53 & 5.74 & 5.74 & 5.74 & 5.74 & 5.74 & 11.71 \\
\hline MsMML & - & 3.48 & 3.48 & - & 3.48 & 3.48 & - \\
\hline MsMMM & 21.10 & 12.51 & 12.51 & 18.64 & 22.01 & 12.51 & 24.22 \\
\hline MsMTM & 23.62 & - & - & - & - & - & 0.28 \\
\hline SwMML & - & - & - & - & - & 0.69 & - \\
\hline DwLMM & 5.79 & 18.29 & 18.29 & 9.82 & 22.80 & 25.94 & 9.82 \\
\hline DwMML & 9.58 & 17.32 & 17.32 & 17.32 & 17.32 & 16.64 & 17.32 \\
\hline DwMMM & 16.89 & 9.18 & 9.18 & 4.64 & 9.18 & 9.18 & 4.64 \\
\hline DwMTM & - & - & 0.03 & - & 0.03 & 0.28 & - \\
\hline
\end{tabular}

and increase stresses associated with competition, disease, and elevated metabolic demand.

\subsubsection{Sandy River basin}

The Sandy River basin (Fig. 1b; Table 1) lies on the western slope of Mount Hood in the Oregon Cascades, and occurs in our second region (central Oregon and portions of western Oregon; Fig. S27 in the Supplement). This basin, as well as much of the western slope of the Oregon Cascades, can be broadly classified into two geologic provinces (Tague and Grant, 2004; Tague et al., 2008): the upper elevations (High Cascades) are characterized by younger basalts with high aquifer permeability, where rain and snowmelt percolate vertically and provide steady recharge from the onset of the rainy season until snowmelt; the lower elevations
(WesternCascades) are characterized by a dissected landscape, low aquifer permeability, and are more responsive to precipitation inputs.

Elevation controls the form of winter precipitation in the Sandy, which can fall as rain, snow, or a rain-snow mix. A general threshold for the rain-snow transition in the Cascades is 800-1200 m (Jefferson et al., 2008; Tague et al., 2008). Above $1200 \mathrm{~m}$, a seasonal snowpack accumulates throughout the winter and melts during the spring (Sproles et al., 2013). The upper portions of the Sandy commonly lie above the rain-snow transition and so have a snowpack with a distinct accumulation and melt period. In contrast, the lower portions are rain-dominated, and snow commonly does not accumulate throughout the winter.

These geologic and climatic controls can be seen in the initial HL distribution for the Sandy (Fig. 8a; Table 5): the upper 

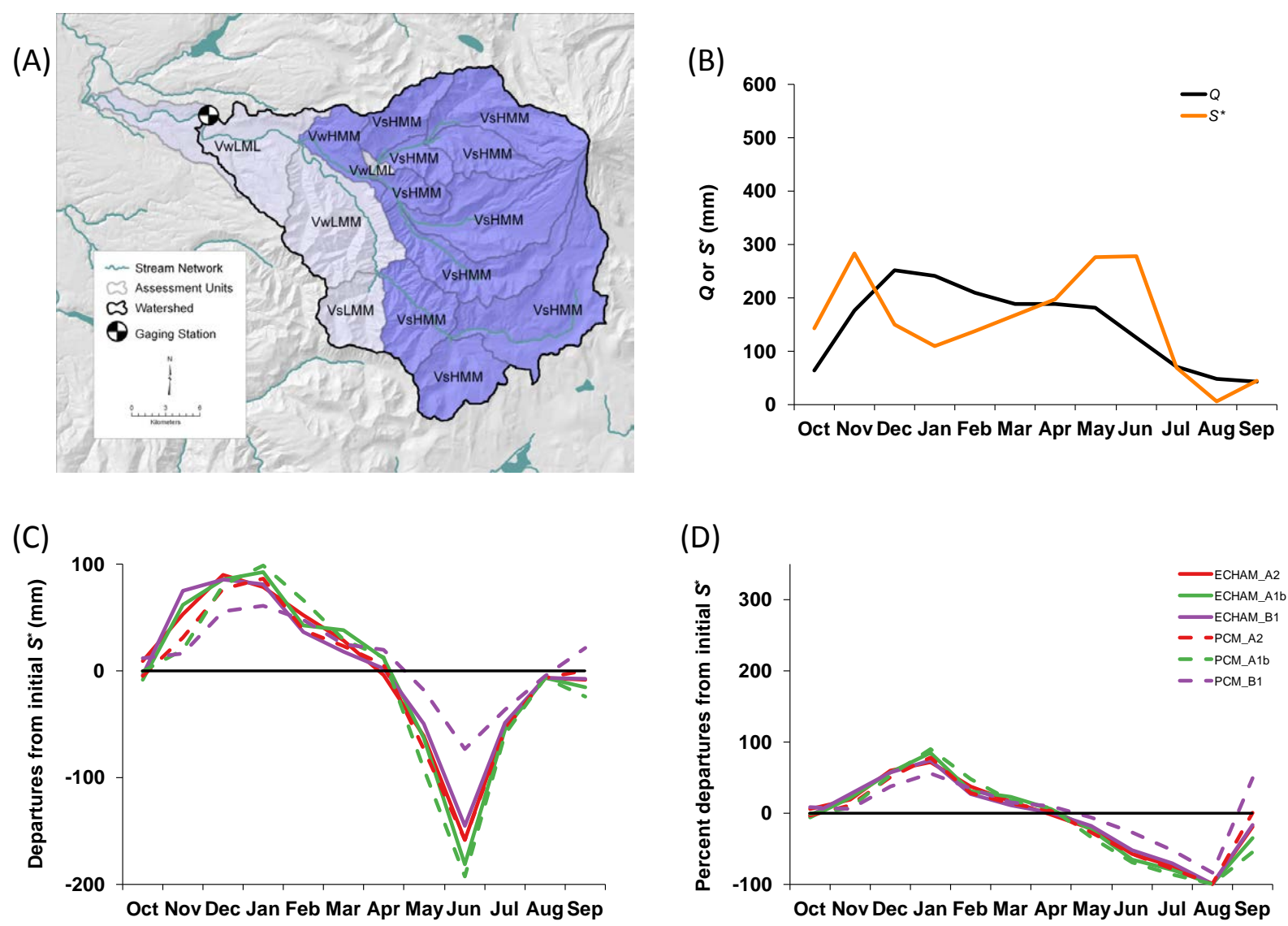

Figure 8. Results for the Sandy River basin, Oregon. (a) Initial (1971-2000) HL distribution; (b) comparison of initial mean monthly discharge $(Q$, in $\mathrm{mm})$ and watershed positive surplus $\left(S^{*}\right.$, in $\left.\mathrm{mm}\right)$; (c) 2041-2070 departures from initial monthly $S^{*}$, by realization; and (d) 2041-2070 percent departures from initial monthly $S^{*}$, by realization.

(eastern) portion is dominated by high aquifer permeability and spring seasonality (due to winter snowpack accumulation and subsequent spring snowmelt). In contrast, the lower (western) portion of the basin is dominated by low aquifer permeability and winter seasonality (due to winter rains). Thus, the HL composition of the Sandy is less uniform than in the Siletz. And while all of the units in the Sandy are very wet, as in the Siletz, the delivery and processing of water by these units varies between the upper and lower portions of the basin. These HL characteristics similarly apply to other basins that are a mix of High Cascades and Western Cascades (for example, the Clackamas, North Santiam, McKenzie, and North Umpqua basins; Fig. S3 in the Supplement; Sproles et al., 2013; Surfleet and Tullos, 2013; Wigington et al., 2013).

The mixed hydrologic characteristics of the Sandy River can be seen in Fig. 8b, where $S^{*}$ rises steadily in October and November. The lag between the November peak in $S^{*}$ and the December peak in $Q$ is due to the recharge of the high permeability aquifer. After November, $S^{*}$ sharply declines, as temperatures fall and more precipitation is stored as seasonal snowpack. Peak winter discharge is therefore lower than in the Siletz (Fig. 7b), since precipitation is not occurring as rain. However, $Q$ stays elevated through April, because of baseflow contributions from the upper Sandy and stormflow generated by rains in the lower, more hydrologically responsive portion of the basin. $S^{*}$ then peaks in May due to snowmelt; this water, along with baseflow, sustains high levels of baseflow through the drier summer months. Over the year, $Q$ is approximately equal to $S^{*}\left(Q / S^{*}=0.96\right.$; Table 1), suggesting minimal groundwater exports from the basin.

The HL climate classes do not change within the Sandy, remaining very wet $(\mathrm{V})$ under all six realizations (Table 5). There are major changes in seasonality, however: units with high aquifer permeability and spring or winter seasonality initially represent 69.8 and $4.0 \%$ of basin area, respectively (Table 5). These numbers change to $0.0-56.0$ and $17.7-73.8 \%$, respectively, representing a $19.7-100.0 \%$ loss in high permeability, spring seasonality class area. Excluding PCM_B1, the range of loss is $63.3-100.0 \%$. This change is even more dramatic for low permeability areas (Table 5): spring and winter seasonality switch from 4.8 and $21.4 \%$, to 0.0 and $26.2 \%$, respectively, representing a $100 \%$ loss of spring seasonality. 
These effects on seasonality are reflected in the changes in $S^{*}$. The changes are consistent across all six realizations (Fig. 8c), though the absolute magnitude of the PCM_B1 results are less than the other five. During the wet winter months, $S^{*}$ values increase due to increased precipitation. Compounding the enhanced precipitation are increased temperatures, which cause the rain-snow transition to rise in elevation, resulting in more winter rain. December, which typically has the most precipitation and the highest $Q$, experiences a 55.3 (PCM_B1) to $90.0 \mathrm{~mm}$ (ECHAM_A2) increase in $S^{*}$ (Fig. 8c), representing a 36.9-60.1\% projected increase (Fig. 8d). This transition from snow to rain also affects $S^{*}$ during the drier summer months: reduced snowpack leads to decreased summer snowmelt and large reductions in $S^{*}$ (Fig. 8c-d): -73.7 (PCM_B1) to -192.8 mm (PCM_A1b) decrease in June, representing 26.6-69.5\% reductions. Proportionately, however, the greatest losses of $S^{*}$ occur in August (83.8-100.0\% reductions). This loss of summer $S^{*}$ will affect the ability of the upper Sandy to sustain streamflow during the summer.

The increases in winter $S^{*}$ and decreases in summer $S^{*}$ suggest the possibility that the Sandy River could experience the increased likelihood of both flooding and drought within the same water year. Greater winter $S^{*}$ could increase the likelihood of moderate flooding, but mitigate the likelihood for extreme flooding events due to reductions in snowpack and, therefore, extreme rain-on-snow events (Jones and Perkins, 2010; Surfleet and Tullos, 2013). Decreases in summer $S^{*}$ are dramatic, and should result in lower spring and summer flows. However, the Sandy (and similar western slope basins that have a High Cascades component) occurs within geological formations where deep groundwater could mediate streamflow response (Tague et al., 2008). The high permeability of the upper portions of the basin are expected to mitigate the impacts on streamflow during the summer months, as rain and snowmelt percolate vertically and emerge as springs lower in the watershed (Tague and Grant, 2004, 2009; Tague et al., 2008). Thus, relative changes in streamflow should be less for this basin, because of the presence of the High Cascades deep groundwater system, compared with areas having faster, shallow subsurface systems (Tague et al., 2008).

The Sandy Basin supports populations of Pacific salmon and trout including the threatened fall and spring chinook salmon (O. tschawytcha), coho salmon, and steelhead (O. mykiss) (Good et al., 2005). Spring chinook salmon, in particular, require cold water during the summer months to support adults holding in the river prior to spawning in the fall; and the deep groundwater sources that provide cold summer streamflows likely contribute to the persistence of these populations under current conditions. The degree to which the groundwater-rich upper basin could continue to support over-summering of chinook salmon and other salmonid populations will be dependent upon the severity of reductions in groundwater recharge and snowmelt runoff. Changes in hydrology could also have implications for winter survival of salmonid embryos and juveniles; i.e., if increased winter streamflows result in increased scour of spawning gravels and altered thermal regimes impact metabolism and growth of juvenile salmonids (Crozier et al., 2008).

\subsubsection{Middle Fork John Day River basin}

The Middle Fork John Day (MFJD; Fig. 1c; Table 1) originates on the southeastern flank of the Blue Mountains in northeastern Oregon, and occurs within our third region (the remainder of the Northern Great Basin and the Blue Mountains of eastern Oregon; Fig. S27 in the Supplement). The MFJD is the largest of the three basins, and is much drier than the two western basins. Winters here are colder than the maritime climate of western Oregon, and summer months are dry and warm. As a result, seasonal snowpack dominates the hydrologic character of the region, and snowmelt comprises the majority of runoff. The MFJD is representative of many basins in eastern Oregon that are similarly snowmeltdominated.

The MFJD is the most diverse of the three basins with respect to HL composition (Table 5; Fig. 9a). The basin is comprised of eleven HL classes, which vary from wet with spring seasonality (i.e., snowmelt-dominated) in the eastern headwaters to dry with winter seasonality at the western mouth (which have the lowest elevations in the valley). Eighty-five percent of the basin has moderate aquifer permeability; the remaining $15 \%$ of the area, located in the middle of the basin (Fig. 9a), has low aquifer permeability. While all of the units in the Siletz and Sandy basins had very wet climate, and therefore contributed to streamflow, the hydrologic character of the MFJD is strongly influenced by headwater assessment units that are wet and snowmelt driven. In addition, this area has moderate aquifer permeability, and so contributes groundwater to baseflow. Although these assessment units comprise only $10 \%$ of basin area, they function as the key sources of water for the system. The rest of the upper basin is mostly units with moist climate and spring seasonality (49\% of basin area), with low to moderate aquifer permeability. These assessment units contribute less water per unit area and less groundwater than the uppermost assessment units. In contrast to the MFJD's upper and middle areas, the lower basin is comprised of units with dry climate $(32 \%$ of basin area), and so contribute little to streamflow.

The $S^{*}$ and $Q$ curves for the MFJD further illustrate how winter snowpack dominates its hydrologic character. As occurred with the Sandy Basin, $S^{*}$ in the MFJD has a bimodal distribution (Fig. 9b). Values rise in November, as precipitation initially occurs as rain, but then fall in December and January due to snow accumulation. $S^{*}$ then begins to rise again in March, due to snowmelt, and peaks in May. $Q$ does not rise in response to the November rains because pore space in the soil column must first be filled. Because less rain falls in the MFJD than in the Sandy, and for a shorter 
(A)

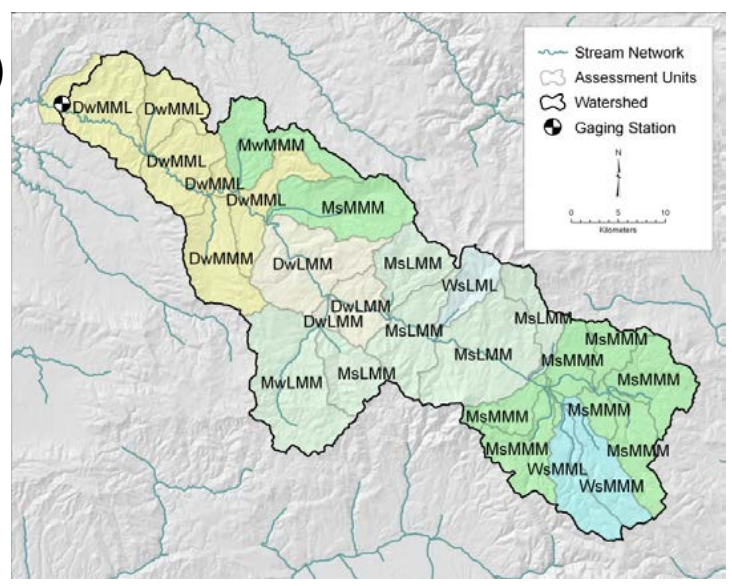

(C)

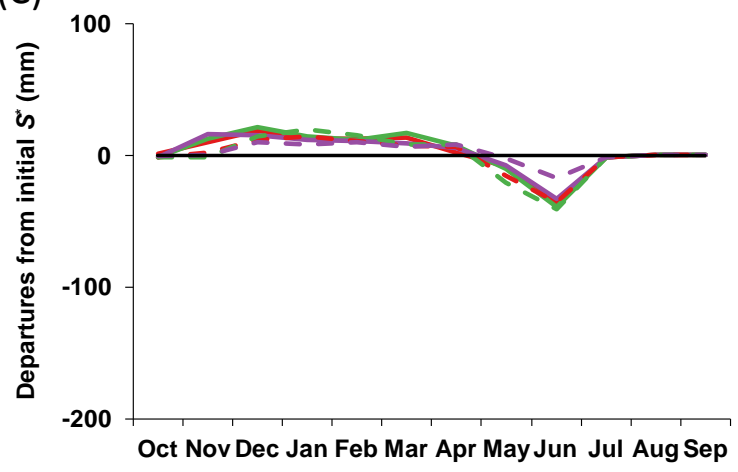

(B)

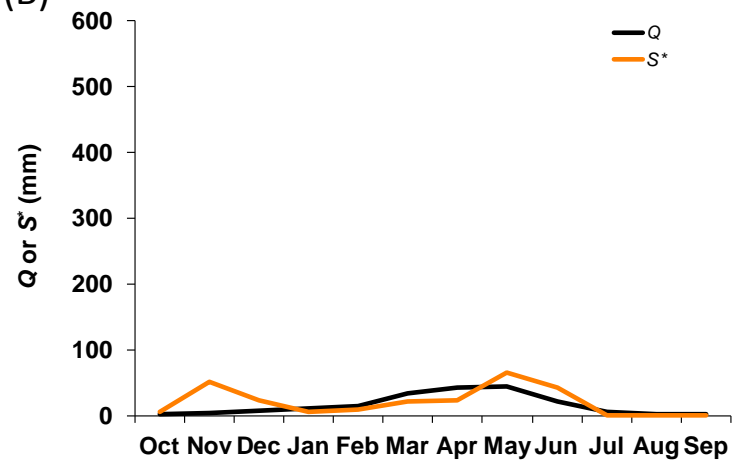

(D)

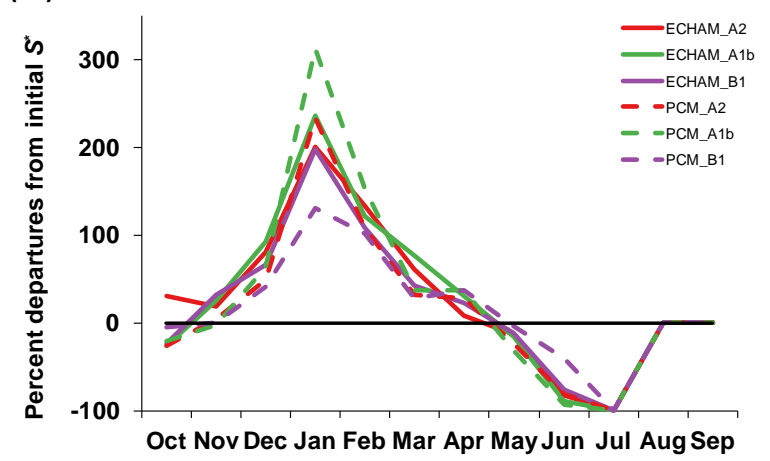

Figure 9. Results for the Middle Fork John Day River basin, Oregon. (a) Initial (1971-2000) HL distribution; (b) comparison of initial mean monthly discharge $(Q$, in $\mathrm{mm})$ and watershed positive surplus $\left(S^{*}\right.$, in $\left.\mathrm{mm}\right)$; (c) 2041-2070 departures from initial monthly $S^{*}$, by realization; and (d) 2041-2070 percent departures from initial monthly $S^{*}$, by realization (August and September values undefined due to division by zeros).

period, runoff remains low throughout the winter, though gradually rising through February. Runoff then increases in March, in response to snowmelt, and peaks in May during the same month when $Q$ peaks. Values for both $S^{*}$ and $Q$ are low from July to the end of the water year in September; low summer runoff values partly reflect irrigation usage. Winter and spring recharge of the moderate permeability aquifer in the upper basin provides some groundwater contributions to baseflow. However, the basin's low $Q / S^{*}$ ratio (0.78; Table 1) suggests that, overall, the MFJD may be losing groundwater.

While projected climate change scenarios had little effect on the climate class of the Siletz and Sandy basins, this is not the case for the MFJD. Wet assessment units are expected to substantially decline under all but the two B1 scenarios, from a total of $10.0 \%$ of basin area to 0.0 $2.2 \%$ (Table 5); all wet climate units disappear under the PCM_A2 and PCM_A1b realizations. Under ECHAM_B1 and PCM_B1, there is relatively little change in the area of wet units ( 9.1 and $11.3 \%$, respectively). The area of moist units also decreases for five of the scenarios, from 57.8 to
$47.3-56.9 \%$. Moist units slightly increase in area to $59.2 \%$ under ECHAM_B1. In contrast to the wet and moist units, dry units mostly increase in area, from 32.3 to $44.8-52.0 \%$ of basin area under all but the B1 realizations; slight reductions to $31.8 \%$ occur for both those realizations. As occurred with the Sandy, the MFJD also is expected to experience major shifts from spring (snowmelt-dominated) to winter (raindominated) seasonality (Table 5). Units with spring seasonality decline in area from 59.2 to $23.9-47.6 \%$, while winter seasonality increases from 40.8 to $52.4-76.1 \%$. This represents a $19.7-59.6 \%$ reduction in snowmelt-dominated area (43.5-59.6\%, excluding PCM_B1).

Under all six realizations, $S^{*}$ increases in the MFJD during the fall and winter months (Fig. 9c). While the overall trend is similar to the other two basins (Figs. 7c, 8c), the MFJD has the lowest magnitude of change. For example, departures in $S^{*}$ for January range from 8.0 (PCM_B1) to $19.3 \mathrm{~mm}$ (PCM_A1b), compared with ranges of 29.6-77.1 and 60.6$98.9 \mathrm{~mm}$ for the Siletz and Sandy, respectively. While these are the smallest of the basin values on an absolute basis, the January departures represent the largest proportional changes 
when compared to initial values (Figs. $7 \mathrm{~d}, 8 \mathrm{~d}, 9 \mathrm{~d}$ ): values range from 130.2 to $312.8 \%$ for the MFJD, vs. 8.0-20.8 and 55.2-90.1\% for the Siletz and Sandy, respectively. This shift to greater January $S^{*}$ represents an increase in rain and large decrease in the amount of moisture available for the snowpack. As a result of less winter snowpack, snowmelt-derived $S^{*}$ is reduced from May to July (Fig. 9c). These declines are largest in June ( -17.3 to $-40.5 \mathrm{~mm}$ ) and smallest in July $(-1.0 \mathrm{~mm}$ for all six realizations). On a proportional basis, however, the July loss represents $100 \%$ of the initial $S^{*}$ values (Fig. 9d).

Given the relationship between $Q$ and $S^{*}$ (Fig. 9b), increased winter $S^{*}$ should lead to modest increases in the slope of the discharge curve between November and April. Loss of spring snowmelt should cause a substantial reduction in discharge from April to June, while July runoff should approach August and September values of 2.2-2.4 mm. The effects of reduced spring $S^{*}$ will not be substantially offset by groundwater if the basin is losing groundwater (i.e., $Q / S^{*}=0.78$; Table 1 ). Reduced spring and summer discharge will negatively impact agriculture in the area, which uses water from the MFJD to flood irrigate approximately 1430 ha of cropland (NMFJDRLAC, 2011). Although this is not a large area, reductions in spring and summer discharge could have serious local effects, since agriculture is the largest private sector economic activity in the basin.

Low summer streamflows and high summer water temperatures are currently a concern for salmonid survival in the MFJD (Good et al., 2005). Summer temperatures can significantly stress populations of salmon and trout in the basin ( $\mathrm{Li}$ et al., 1994), driving distributional patterns and use of thermal refuges (Torgersen et al., 1999). In 2007 and 2013, the MFJD experienced die-offs of 118 and 183 wild adult chinook salmon, respectively, due to high summer water temperatures (http://www.dfw.state.or.us/news/2007/ july/071907.asp; http://www.dfw.state.or.us/news/2013/july/ 071213.asp). Winter and spring temperatures and hydrologic regimes also strongly regulate life history and distributional patterns of salmonids in the basin; for example, influencing the distribution and abundance of steelhead redds (Falke et al., 2013) and the expression of anadromy in steelhead (McMillan et al., 2012). Increased winter runoff is not likely to have major effects on overwintering mortality of salmonids, since initial values and absolute changes are low. However, altered thermal conditions during the winter months could have significant ecological repercussions for anadromous fish (McMillan et al., 2012; Falke et al., 2013). The effects on salmonids due to reductions in spring and summer $S^{*}$ could be even more severe, due to several factors. First, reductions in the amount of water will mean less available habitat. Second, the timing of minimum summer streamflows may increasingly co-occur with the period of maximum temperatures, resulting in multiple negative effects, including mortality, on cold-water fishes (Arismendi et al., 2013; Ebersole et al., 2014). Third, reduced $S^{*}$ during the spring could decrease the number of cold-water patches that salmonids use to escape high mainstem temperatures during the late July-early August period. Ebersole et al. (2014) examined tributary-mainstem confluences at three basins in northeastern Oregon, including the MFJD. They found that cold-water patches were present at $53 \%$ of all observed confluences (60\% for the MFJD). Differences in temperature between cold-water patches and corresponding streamflow were greatest during the hottest time of the day, when coldwater fish are most at risk. The single most important factor that predicted the probability of cold-water patch occurrence was May $S^{\prime}$ (Ebersole et al., 2014). The effects of climate change on May $S^{\prime}$ are likely to be greater than our estimates for $S^{*}$, since the latter does not incorporate moisture deficits (compare Eqs. 2 and 3). Thus, the projected trends in spring $S^{*}$ could reduce the number of these cold-water patches. Given the combined effects of these three factors, salmonids in the MFJD could be particularly vulnerable to climate change.

\subsubsection{Relative vulnerability of salmonids}

Based on our analysis of the three case study basins, we would expect the MFJD - and similar basins occurring in the eastern portion of the Northern Great Basin and the Blue Mountains of eastern Oregon (Fig. S27 in the Supplement) - to have the highest vulnerability with respect to both relative loss of winter snowpack and summer streamflow. The basin should also be most vulnerable with respect to impacts to threatened and nonthreatened salmonids, due to the relatively high magnitudes of changes in habitat suitability and availability, particularly during the summer months (see also Ruesch et al., 2012). The Siletz Basin, as well as other basins within the mountainous portions of western Oregon (Fig. S27 in the Supplement), should be the least hydrologically vulnerable to climate change, since changes in winter $S^{*}$ are relatively small, compared to current conditions, and because there is relatively little linkage between winter rains and summer flows. Summer streamflows and temperatures are already a concern in the basin, however, so any decreases in flow or increases in temperature could have negative effects on salmonids. The Sandy Basin, as well as others in the High Cascades, east flank Cascades, and eastern portion of the Northern Great Basin (Fig. S27 in the Supplement), should have intermediate vulnerability with respect to hydrology, since the effects of relatively large changes in winter and summer $S^{*}$ will increase winter rains and reduce spring and summer snowmelt. However, high permeability aquifers will moderate these impacts. The effects on salmonids will be highly contingent upon the net effects of hydrologic and thermal regime shifts on phenology and environmental suitability for growth, development, and survival (Crozier et al., 2008). 


\section{Summary and conclusions}

We examined how a range of mid-21st century climate change realizations would affect the distribution of HLs in Oregon, using climate output from the ECHAM and PCM general circulation models run with three $\mathrm{CO}_{2}$ emission scenarios (A2, A1b, and B1). Statewide results found that changes in climate class affected a modest number of study units (4.4-18.3\%). However, there were major changes in seasonality class for five of the realizations, with $56.8-68.4 \%$ loss of spring seasonality and $100 \%$ loss of summer seasonality. Although seasonality changed less under the PCM_B1 realization - 19.7 and $42.9 \%$ for spring and summer seasonality, respectively - the changes were still substantial. Overall, in our simulations Oregon shifts from initially having $12.9 \%$ snow-dominated units to $4.2-$ $5.6 \%$ snow-dominated units under the five realizations, representing a $56.2-67.8 \%$ reduction in snowmelt-dominated units. Under PCM_B1, the snow-dominated area declines to $10.4 \%$, representing a $19.3 \%$ reduction. The shifts in seasonality occur because $S^{*}$ generally increases in the fall and winter, representing a loss of snowpack, and decreases in the spring and fall, due to reduced snowmelt.

The specific effects of these changes in timing and delivery of $S^{*}$ are mediated by the geology of the basin. We discuss in detail results from three case study basins to demonstrate how the HL approach can be useful for understanding climate change impacts in diverse hydroclimatic and geologic settings, and to illustrate how the approach could support management. Basins such as the Siletz are rain-dominated with low permeability, have relatively low internal water storage and, as a result, water drains rapidly into the streams and produces very low summer baseflows. Because precipitation is already delivered as rain, there is relatively little effect on timing of delivery. Also, because $S^{*}$ values are initially large, changes in $S^{*}$ are proportionately small. The Sandy Basin, however, includes higher-elevation areas that accumulate snowpack, and those areas experience shifts from snowmelt-dominated to rain-dominated. While this would be expected to have an effect on spring and summer baseflows, high aquifer permeability in such basins has the potential to moderate these effects. The MFJD, in northeastern Oregon, is the most dependent of the three basins on spring snowmelt. Thus, it is the most impacted area, because of both changes in seasonality and switches to drier climate classes. Moderate aquifer permeability in the upper basin is less able to reduce these impacts, compared with the Sandy. Our analysis suggests that the MFJD and other irrigated areas in semiarid eastern Oregon could be particularly vulnerable to the effects of climate change. Decreased spring and summer snowmelt from reduced $S^{*}$ could also have greater impacts on salmonids in the MFJD and similar areas, compared with other regions.

While the ECHAM model has higher sensitivity to climate change than the PCM model (Intergovernmental Panel on
Climate Change, 2007), as discussed previously, we found that statewide changes in climate class (Tables 2 and 3; Fig. 2) and FMI (Fig. 3) were greater for the PCM model. This demonstrates the anticipated regional variability of climate change. In addition, results for statewide seasonality, $S^{\prime}$, and basin $S^{*}$ values (Figs. 4, 5, 7, 8, 9) were variable with respect to the two models. Regarding $\mathrm{CO}_{2}$ emissions, results consistently showed greater impacts for the A1b scenario, compared to A2. While the A2 scenario ultimately results in the highest emissions by the end of the 21 st century, A1b produces greater emissions for the mid-century time frame we consider in this paper (Nakićenović et al., 2000). Thus, our finding of greater impacts under the A1b scenario is consistent with the different trajectories of the $\mathrm{A} 2$ and A1b emission scenarios for the mid-century period that we analyze.

The accuracy of our evaluation depends on the accuracy of the ECHAM and PCM models, which were drawn from CMIP3. Both the ECHAM and PCM models are within the performance range of all major IPCC climate models for predicting historical data (Gleckler et al., 2008). However, the accuracy of a model with respect to historical data does not necessarily reflect its accuracy for simulations of future conditions. Furthermore, the accuracy of our evaluation depends on the accuracy of the initial HL classification. It is not possible to directly assess the HL accuracy per se, since this is a conceptual classification. However, it is based on the best available GIS data, and has been shown to be useful in distinguishing between different hydrologic behaviors (Wigington et al., 2013; Patil et al., 2014).

In this paper, we have demonstrated that the Wigington et al. (2013) HL approach can provide a method for mapping and interpreting vulnerability to climate change. The HLs provide integrated measures of the key drivers of the hydrologic characteristics of a watershed. This information allows for a broad-scale (e.g., statewide) analysis that provides a systematic understanding of how climate change will impact the hydrologic cycle across geographies. In addition, effects of climate change on individual basins can be evaluated by combining the effects of constituent assessment units. We make use of the classification itself - changes in the distribution of the climate and seasonality classes - as well as changes in the variables used to define these classes (FMI, Eq. 1, and $S^{\prime}$, Eq. 2, for assessment units, and $S^{*}$, Eq. 3, for basins) to evaluate these effects. The two modified surplus terms represent the amount of water entering the system from rain and snowmelt, and so are the major drivers of runoff for most of Oregon. We then utilize the relationship between modified surplus and runoff to make inferences about how climate change will affect basin streamflow, using aquifer permeability class to account for the mitigating effects of geology.

Our analysis has several limitations. First, the relationship between modified surplus and runoff is not quantified, so our conclusions regarding future discharge must be interpreted for each basin by examining the relationships between $Q$ and 
$S^{*}$ (Figs. 7b, 8b, 9b). The use of a model that estimates $Q$ from $S^{*}$ would allow for more objective conclusions.

Second, our analysis makes use of 30-year normals for the 2041-2070 period. As such, our study ignores effects from any future changes in extreme hydroclimatic events. For example, our approach does not address the frequency of the heaviest downpours, which are likely to increase with climate change (Intergovernmental Panel on Climate Change, 2012). While our analysis can provide managers with an understanding of how average monthly hydrologic conditions will change, the results would not be appropriate for flood or drought planning. Furthermore, we emphasize again that we examined only a relatively small number of future climate simulations (two GCMs, each run with three emissions scenarios), in keeping with the proof-of-concept nature of this study. A much fuller representation of climate modelbased uncertainty would be desirable in future work, to span the widest possible range of potential future water resources outcomes.

Additionally, we note that our analysis made use of the CMIP3 multimodel data set that was evaluated in the IPCC Fourth Assessment Report (Intergovernmental Panel on Climate Change, 2007). Although more recent modeling results are now available (the CMIP5 ensemble), we did not use these in part because the model runs evaluated in the IPCC Fifth Assessment Report were not yet published at the time of our analysis. In addition, while CMIP3 represents an earlier generation of models (and greenhouse gas scenarios) compared to CMIP5, most of the basic assumptions and model structures are very similar. Also, the new representative concentration pathways greenhouse gas scenarios map quite closely to the previous generation (Special Report on Emissions Scenarios) scenarios. The initial diagnostic analysis of results for North America across a wide range of climate variables (e.g., temperature, precipitation, winds, humidity, etc.) and dynamical processes (e.g., El Niño-Southern Oscillation, storm tracks, etc.) conclude that there are few substantive differences in the results and model performance for CMIP3 and CMIP5 (Sheffield et al., 2013a, b).

Third, the Oregon HLs do not deal with the influences of vegetation, land use, or other human activities - all of which could influence vulnerability to climate change (Nolin, 2012) - although the HL approach could serve as a framework for evaluating these effects (Wigington et al., 2013). These factors could exacerbate or mitigate against climate impacts.

The strength of our approach is that it can be applied to similarly classified, ungaged basins. In such a case, the $S^{*}$ curve for the ungaged basin, which can be produced for any basin in Oregon through the use of the $400 \mathrm{~m}$ PRISM data and the Leibowitz et al. (2012) snowmelt model, is compared with the runoff curve from a similarly classified, gaged basin. The interpreted runoff results can then be used to evaluate overall vulnerability with respect to quantity and timing of discharge, as well as resources and constituents dependent on or associated with streamflow, such as salmonids. The approach also allows relative ranking of vulnerability, e.g., the MFJD is more vulnerable to climate effects than the Sandy because it is more dependent on snowmelt and has less of a mitigating geology. We believe that such vulnerability information can help inform management responses and adaptation to climate change both at regional and basin scales.

\section{The Supplement related to this article is available online at doi:10.5194/hess-18-3367-2014-supplement.}

Acknowledgements. Thanks to Tom Johnson, Anne Nolin, Alan Vette, Hongkai Gao, and two anonymous reviewers for useful comments. We acknowledge the modeling groups, the Program for Climate Model Diagnosis and Intercomparison and the WCRP's Working Group on Coupled Modelling for their roles in making available the WCRP CMIP3 multimodel data set. Support for this data set was provided by the Office of Science, US Department of Energy. The information in this document has been funded entirely by the US Environmental Protection Agency, in part through an Oak Ridge Institute for Science and Education (ORISE) postdoctoral agreement. This manuscript has been subjected to Agency review and has been approved for publication. Mention of trade names or commercial products does not constitute endorsement or recommendation for use.

Edited by: E. Morin

\section{References}

Abatzoglou, J. T.: Influence of the PNA on declining mountain snowpack in the Western United States, Int. J. Climatol., 31, 1135-1142, doi:10.1002/joc.2137, 2011.

Arismendi, I., Safeeq, M., Johnson, S. L., Dunham, J. B., and Haggerty, R.: Increasing synchrony of high temperature and low flow in western North American streams: double trouble for coldwater biota?, Hydrobiologia, 712, 61-70, 2013.

Barnett, T. P., Adam, J. C., and Lettenmaier, D. P.: Potential impacts of a warming climate on water availability in snow-dominated regions, Nature, 438, 303-309, doi:10.1038/nature04141, 2005.

Battin, J., Wiley, M. W., Ruckelshaus, M. H., Palmer, R. N., Korb, E., Bartz, K. K., and Imaki, H.: Projected impacts of climate change on salmon habitat restoration, P. Natl. Acad. Sci., 104, 6720-6725, doi:10.1073/pnas.0701685104, 2007.

Beechie, T., Buhle, E., Ruckelshaus, M., Fullerton, A., and Holsinger, L.: Hydrologic regime and the conservation of salmon life history diversity, Biol. Conserv., 130, 560-572, 2006.

Bernhardt, E. S., Palmer, M., Allan, J., Alexander, G., Barnas, K., Brooks, S., Carr, J., Clayton, S., Dahm, C., and Follstad-Shah, J.: Synthesizing U.S. river restoration efforts, Science, 308, 636637, 2005.

Cairns, M. A., Ebersole, J. L., Baker, J. P., Wigington, P. J., Lavigne, H. R., and Davis, S. M.: Influence of summer stream temperatures on black spot infestation of juvenile coho salmon in the Oregon coast range, Trans. Am. Fish. Soc., 134, 1471-1479, 2005. 
Chapman, D. W.: Food and space as regulators of salmonid populations in streams, Am. Nat., 100, 345-355, 1966.

Congalton, R. G.: A review of assessing the accuracy of classifications of remotely sensed data, Remote Sens. Environ., 37, 35-46, doi:10.1016/0034-4257(91)90048-b, 1991.

Crozier, L., Hendry, A., Lawson, P., Quinn, T., Mantua, N., Battin, J., Shaw, R., and Huey, R.: Potential responses to climate change in organisms with complex life histories: evolution and plasticity in Pacific salmon, Evolut. Appl., 1, 252-270, 2008.

Daly, C., Halbleib, M., Smith, J. I., Gibson, W. P., Doggett, M. K., Taylor, G. H., Curtis, J., and Pasteris, P. P.: Physiographically sensitive mapping of climatological temperature and precipitation across the conterminous United States, Int. J. Climatol., 28, 2031-2064, doi:10.1002/joc.1688, 2008.

Dozier, J.: Mountain hydrology, snow color, and the fourth paradigm, EOS Trans. AGU, 92, 373-374, doi:10.1029/2011eo430001, 2011.

Ebersole, J. L., Wigington Jr., P. J., Leibowitz, S. G., Comeleo, R. L., and Van Sickle, J.: Predicting the occurrence of cold water patches at intermittent and ephemeral tributary confluences with warm rivers, Freshwater Sci., doi:10.1086/678127, in press, 2014.

Elsner, M. M., Cuo, L., Voisin, N., Deems, J. S., Hamlet, A. F., Vano, J. A., Mickelson, K. E. B., Lee, S.-Y., and Lettenmaier, D. P.: Implications of 21st century climate change for the hydrology of Washington State, Climatic Change, 102, 225-260, 2010.

Falke, J. A., Dunham, J. B., Jordan, C. E., McNyset, K. M., and Reeves, G. H.: Spatial ecological processes and local factors predict the distribution and abundance of spawning by steelhead (Oncorhynchus mykiss) across a complex riverscape, PloS One, 8, e79232, doi:10.1371/journal.pone.0079232, 2013.

Feddema, J. J.: A revised Thornthwaite-type global climate classification, Physical Geography, 26, 442-466, doi:10.2747/02723646.26.6.442, 2005.

Fleming, S. W., Whitfield, P. H., Moore, R. D., and Quilty, E. J.: Regime-dependent streamflow sensitivities to Pacific climate modes cross the Georgia-Puget transboundary ecoregion, Hydrol. Process., 21, 3264-3287, doi:10.1002/hyp.6544, 2007.

Fritze, H., Stewart, I. T., and Pebesma, E.: Shifts in western North American snowmelt runoff regimes for the recent warm decades, J. Hydrometeorol., 12, 989-1006, doi:10.1175/2011jhm1360.1, 2011.

Gao, H., Hrachowitz, M., Fenicia, F., Gharari, S., and Savenije, H. H. G.: Testing the realism of a topography-driven model (FLEXTopo) in the nested catchments of the Upper Heihe, China, Hydrol. Earth Syst. Sci., 18, 1895-1915, doi:10.5194/hess-18-18952014, 2014.

Gleckler, P. J., Taylor, K. E., and Doutriaux, C.: Performance metrics for climate models, J. Geophys. Res.-Atmos., 113, D06104, doi:10.1029/2007JD008972, 2008.

Gonthier, J. B.: A description of aquifer units in eastern Oregon, Water Resources Investigations Report 84-4095, US Geological Survey, Portland, Oregon, 1984.

Good, T., Waples, R., and Adams, P.: Updated status of federally listed ESUs of West Coast salmon and steelhead, US Dept. Commerce, Seattle, Washington, 2005.
Groisman, P. Y., Knight, R. W., Easterling, D. R., Karl, T. R., Hegerl, G. C., and Razuvaev, V. A. N.: Trends in intense precipitation in the climate record, J. Climate, 18, 1326-1350, doi:10.1175/jcli3339.1, 2005.

Groisman, P. Y., Knight, R. W., and Karl, T. R.: Changes in intense precipitation over the central United States, J. Hydrometeorol., 13, 47-66, doi:10.1175/jhm-d-11-039.1, 2012.

Hamon, W. R.: Estimating potential evapotranspiration, J. Hydraul. Div.-ASCE, 87, 107-120, 1961.

Harvey, B. C., Nakamoto, R. J., and White, J. L.: Reduced streamflow lowers dry-season growth of rainbow trout in a small stream, Trans. Am. Fish. Soc., 135, 998-1005, 2006.

Homer, C., Dewitz, J., Fry, J., Coan, M., Hossain, N., Larson, C., Herold, N., McKerrow, A., VanDriel, J. N., and Wickham, J. D.: Completion of the 2001 National Land Cover Database for the conterminous United States, Photogramm. Eng. Remote Sens., 73, 337-341, 2007.

Huppert, D. D.: Snake River salmon recovery: quantifying the costs, Contemp. Econ. Policy, 17, 476-491, 1999.

Intergovernmental Panel on Climate Change: Climate change 2007: The physical science basis, Contribution of Working Group I to the Fourth Assessment Report of the Intergovernmental Panel on Climate Change, New York, 2007.

Intergovernmental Panel on Climate Change: Managing the risks of extreme events and disasters to advance climate change adaptation: A pecial report of Working Groups I and II of the Intergovernmental Panel on Climate Change, Cambridge University Press, Cambridge, UK, 582 pp., 2012.

Jefferson, A., Nolin, A., Lewis, S., and Tague, C.: Hydrogeologic controls on streamflow sensitivity to climate variation, Hydrol Process., 22, 4371-4385, doi:10.1002/hyp.7041, 2008.

Johnson, T. E. and Weaver, C. P.: A framework for assessing climate change impacts on water and watershed systems, Environ. Manage., 43, 118-134, 2009.

Johnson, T. E., Butcher, J. B., Parker, A., and Weaver, C. P.: Investigating the sensitivity of U.S. streamflow and water quality to climate change: U.S. EPA Global Change Research Program's 20 Watersheds Project, J. Water Resour. Pl. Manage., 138, 453464, doi:10.1061/(asce)wr.1943-5452.0000175, 2012.

Jones, J. A. and Perkins, R. M.: Extreme flood sensitivity to snow and forest harvest, western Cascades, Oregon, United States, Water Resour. Res., 46, W12512, doi:10.1029/2009WR008632, 2010.

Karl, T. R., Melillo, J. M., and Peterson, T. C.: Global climate change impacts in the United States, Cambridge University Press, 2009.

Kharin, V. V., Zwiers, F. W., Zhang, X., and Wehner, M.: Changes in temperature and precipitation extremes in the CMIP5 ensemble, Climatic Change, 119, 345-357, doi:10.1007/s10584-013-07058, 2013.

Kundzewicz, Z. W., Mata, L. J., Arnell, N. W., Doll, P., Kabat, P., Jimenez, B., Miller, K., Oki, T., Zekai, S., and Shiklomanov, I.: Freshwater resources and their management, Cambridge, UK, , 173-210, 2007.

Leibowitz, S. G., Wigington Jr., P. J., Comeleo, R. L., and Ebersole, J. L.: A temperature-precipitation-based model of thirtyyear mean snowpack accumulation and melt in Oregon, USA, Hydrol. Process., 26, 741-759, doi:10.1002/hyp.8176, 2012. 
Li, H. W., Lamberti, G. A., Pearsons, T. N., Tait, C. K., Li, J. L., and Buckhouse, J. C.: Cumulative effects of riparian disturbances along high desert trout streams of the John Day Basin, Oregon, Trans. Am. Fish. Soc., 123, 627-640, 1994.

Loy, W. G., Allan, S., Buckley, A. R., and Meacham, J. E.: Atlas of Oregon, 2nd Edn., University of Oregon Press, Eugene, Oregon, 301 pp., 2001.

Luce, C. H. and Holden, Z. A.: Declining annual streamflow distributions in the Pacific Northwest United States, 1948-2006, Geophys. Res. Lett., 36, L16401, doi:10.1029/2009g1039407, 2009.

Mantua, N., Tohver, I., and Hamlet, A.: Climate change impacts on streamflow extremes and summertime stream temperature and their possible consequences for freshwater salmon habitat in Washington State, Climatic Change, 102, 187-223, doi:10.1007/s10584-010-9845-2, 2010.

Maurer, E. P., Brekke, L., Pruitt, T., and Duffy, P. B.: Fine-resolution climate projections enhance regional climate change impact studies, EOS Trans. Am. Geophys. Union, 88, 504-504, 2007.

McClure, M. M., Alexander, M. A., Borggaard, D., Boughton, D., Crozier, L., Griffis, R., Jorgensen, J. C., Lindley, S. T., Nye, J., Rowland, J., Seney, E. E., Snover, A., Toole, C., and Van Houtan, K.: Incorporating climate science in applications of the U.S. Endangered Species Act for aquatic species, Conserv. Biol., 27, 1222-1233, doi:10.1111/cobi.12166, 2013.

McCullough, D. A., Bartholow, J. M., Jager, H. I., Beschta, R. L., Cheslak, E. F., Deas, M. L., Ebersole, J. L., Foott, J. S., Johnson, S. L., Marine, K. R., Mesa, M. G., Petersen, J. H., Souchon, Y., Tiffan, K. F., and Wurtsbaugh, W. A.: Research in thermal biology: burning questions for coldwater stream fishes, Rev. Fish. Sci., 17, 90-115, 2009.

McFarland, W. D.: A description of aquifer units in western Oregon, Open-File Report 82-165, US Geological Survey, Portland, Oregon, 1983.

McMillan, J. R., Dunham, J. B., Reeves, G. H., Mills, J. S., and Jordan, C. E.: Individual condition and stream temperature influence early maturation of rainbow and steelhead trout, Oncorhynchus mykiss, Environ. Biol. Fishes, 93, 343-355, 2012.

Meehl, G. A., Covey, C., Delworth, T., Latif, M., McAvaney, B., Mitchell, J. F. B., Stouffer, R. J., and Taylor, K. E.: The WCRP CMIP3 multimodel dataset - A new era in climate change research, B. Am. Meteorol. Soc., 88, 1383-1394, doi:10.1175/bams-88-9-1383, 2007.

Milly, P. C. D., Betancourt, J., Falkenmark, M., Hirsch, R. M., Kundzewicz, Z. W., Lettenmaier, D. P., and Stouffer, R. J.: Stationarity is dead: whither water management?, Science, 319, 573-574, doi:10.1126/science.1151915, 2008.

Mote, P. W. and Salathé, E.: Future climate in the Pacific Northwest, Climatic Change, 102, 29-50, doi:10.1007/s10584-010-9848-z, 2010.

Mote, P. W., Hamlet, A. F., Clark, M. P., and Lettenmaier, D. P.: Declining mountain snowpack in western North America, B. Am. Meteorol. Soc., 86, 39-49, 2005.

Nakićenović, N., Alcamo, J., Davis, G., de Vries, B., Fenhann, J., Gaffin, S., Gregory, K., Grübler, A., Jung, T. Y., Kram, T., La Rovere, E. L., Michaelis, L., Mori, S., Morita, T., Pepper, W., Pitcher, H., Price, L., Riahi, K., Roehrl, A., Rogner, H.-H., Sankovski, A., Schlesinger, M., Shukla, P., Smith, S., Swart, R., van Rooijen, S., Victor, N., and Dadi, Z.: Special Report on Emissions Scenarios: A Special Report of Working Group III of the
Intergovernmental Panel on Climate Change, http://www.grida. no/climate/ipcc/emission/index.htm, Cambridge, 599 pp., 2000.

NMFJDRLAC: North and Middle Forks John Day River Agricultural Water Quality Management Area Plan, North and Middle Forks John Day River Local Advisory Committee, with assistance from Oregon Department of Agriculture and Monument Soil and Water Conservation District, $39 \mathrm{pp}$., http://www.oregon.gov/ODA/shared/Documents/Publications/ NaturalResources/JohnDayNMFAWQMAreaPlan.pdf (last access: 2 September 2014), 2011.

Nolin, A. W.: Perspectives on climate change, mountain hydrology, and water resources in the Oregon Cascades, USA, Mount. Res. Develop., 32, S35-S46, doi:10.1659/mrd-journald-11-00038.s1, 2012.

Nolin, A. W. and Daly, C.: Mapping "at risk" snow in the Pacific Northwest, J. Hydrometeorol., 7, 1164-1171, doi:10.1175/jhm543.1, 2006.

Patil, S. D., Wigington, P. J. J., Leibowitz, S. G., and Comeleo, R. L.: Use of hydrologic landscape classification to diagnose streamflow predictability in Oregon, J. Am. Water Resour. Assoc., 50, 762-776, doi:10.1111/jawr.12143, 2014.

Quinn, T. P.: The behavior and ecology of Pacific salmon and trout, University of Washington Press, Seattle, WA, 378 pp., 2005.

Ruesch, A. S., Torgersen, C. E., Lawler, J. J., Olden, J. D., Peterson, E. E., Volk, C. J., and Lawrence, D. J.: Projected climate-induced habitat loss for salmonids in the John Day River network, Oregon, USA, Conserv. Biol., 26, 873-882, 2012.

Ruffner, J. A.: Climates of the states: National Oceanic and Atmospheric Administration narrative summaries, tables, and maps for each state, with overview of state climatologist programs, Gale Research Co., Detroit, Michigan, 1985.

Safeeq, M., Grant, G. E., Lewis, S. L., and Tague, C. L.: Coupling snowpack and groundwater dynamics to interpret historical streamflow trends in the western United States, Hydrol. Process., 27, 655-668, doi:10.1002/hyp.9628, 2013.

Savenije, H. H. G.: HESS Opinions "Topography driven conceptual modelling (FLEX-Topo)”, Hydrol. Earth Syst. Sci., 14, 26812692, doi:10.5194/hess-14-2681-2010, 2010.

Sawicz, K., Wagener, T., Sivapalan, M., Troch, P. A., and Carrillo, G.: Catchment classification: empirical analysis of hydrologic similarity based on catchment function in the eastern USA, Hydrol. Earth Syst. Sci., 15, 2895-2911, doi:10.5194/hess-15-28952011, 2011.

Service, R. F.: As the west goes dry, Science, 303, 1124-1127, 2004.

Sheffield, J., Barrett, A. P., Colle, B., Fernando, D. N., Fu, R., Geil, K. L., Hu, Q., Kinter, J., Kumar, S., Langenbrunner, B., Lombardo, K., Long, L. N., Maloney, E., Mariotti, A., Meyerson, J. E., Mo, K. C., Neelin, J. D., Nigam, S., Pan, Z., Ren, T., RuizBarradas, A., Serra, Y. L., Seth, A., Thibeault, J. M., Stroeve, J. C., Yang, Z., and Yin, L.: North American climate in CMIP5 experiments, Part I: Evaluation of historical simulations of continental and regional climatology, J. Climate, 26, 9209-9245, 2013a.

Sheffield, J., Langenbrunner, B., Meyerson, J. E., Neelin, J. D., Camargo, S. J., Fu, R., Hu, Q., Jiang, X., Karnauskas, K. B., and Kim, S. T.: North American climate in CMIP5 experiments, Part II: Evaluation of historical simulations of intra-seasonal to decadal variability, J. Climate, 26, 9247-9290, 2013 b. 
Sivapalan, M., Takeuchi, K., Franks, S. W., Gupta, V. K., Karambiri, H., Lakshmi, V., Liang, X., McDonnell, J. J., Mendiondo, E. M., O'Connell, P. E., Oki, T., Pomeroy, J. W., Schertzer, D., Uhlenbrook, S., and Zehe, E.: IAHS Decade on Predictions in Ungauged Basins (PUB), 2003-2012: Shaping an exciting future for the hydrological sciences, Hydrolog. Sci. J., 48, 857880, doi:10.1623/hysj.48.6.857.51421, 2003.

Sproles, E. A., Nolin, A. W., Rittger, K., and Painter, T. H.: Climate change impacts on maritime mountain snowpack in the Oregon Cascades, Hydrol. Earth Syst. Sci., 17, 2581-2597, doi:10.5194/hess-17-2581-2013, 2013.

Stewart, I. T.: Changes in snowpack and snowmelt runoff for key mountain regions, Hydrol. Process., 23, 78-94, doi:10.1002/hyp.7128, 2009.

Stewart, I. T., Cayan, D. R., and Dettinger, M. D.: Changes in snowmelt runoff timing in western North America under a 'business as usual' climate change scenario, Climatic Change, 62, 217-232, 2004.

Stewart, I. T., Cayan, D. R., and Dettinger, M. D.: Changes toward earlier streamflow timing across western North America, J. Climate, 18, 1136-1155, 2005.

Stout, H., Lawson, P., Bottom, D., Cooney, T., Ford, M., Jordan, C., Kope, R., Kruzic, L., Pess, G., and Reeves, G.: Scientific conclusions of the status review for Oregon Coast coho salmon (Oncorhynchus kisutch), US Department of Commerce, NOAA Technical Memorandum NMFS-NWFSC-118, p. 242, NOAA, Seattle, Washington, 2012.

Surfleet, C. G. and Tullos, D.: Variability in effect of climate change on rain-on-snow peak flow events in a temperate climate, J. Hydrol., 479, 24-34, doi:10.1016/j.jhydrol.2012.11.021, 2013.

Surfleet, C. G., Tullos, D., Chang, H., and Jung, I.-W.: Selection of hydrologic modeling approaches for climate change assessment; a comparison of model scale and structures, J. Hydrol., 464-465, 233-248, doi:10.1016/j.jhydrol.2012.07.012, 2012.

Tague, C. and Grant, G. E.: A geological framework for interpreting the low-flow regimes of Cascade streams, Willamette River Basin, Oregon, Water Resour. Res., 40, W04303, doi:10.1029/2003wr002629, 2004.
Tague, C. and Grant, G. E.: Groundwater dynamics mediate low-flow response to global warming in snowdominated alpine regions, Water Resour. Res., 45, W07421, doi:10.1029/2008wr007179, 2009.

Tague, C., Grant, G., Farrell, M., Choate, J., and Jefferson, A.: Deep groundwater mediates streamflow response to climate warming in the Oregon Cascades, Climatic Change, 86, 189-210, doi:10.1002/hyp.8067, 2008.

Tague, C. L., Choate, J. S., and Grant, G.: Parameterizing subsurface drainage with geology to improve modeling streamflow responses to climate in data limited environments, Hydrol. Earth Syst. Sci., 17, 341-354, doi:10.5194/hess-17-341-2013, 2013.

Taylor, G. H. and Hannan, C.: The climate of Oregon: From rain forest to desert, Oregon State University Press, Corvallis, 1999.

Thornthwaite, C. W.: An approach toward a rational classification of climate, Geogr. Rev., 38, 55-94, 1948.

Torgersen, C. E., Price, D. M., Li, H. W., and McIntosh, B. A.: Multiscale thermal refugia and stream habitat associations of chinook salmon in northeastern Oregon, Ecol. Appl., 9, 301-319, 1999.

Tschaplinski, P. J. and Hartman, G. F.: Winter distribution of juvenile coho salmon (Oncorhynchus kisutch) before and after logging in Carnation Creek, British Columbia, and some implications for overwinter survival, Can. J. Fish. Aquat. Sci., 40, 452 461, 1983.

US EPA: Watershed modeling to assess the sensitivity of streamflow, nutrient, and sediment loads to potential climate change and urban development in 20 US watersheds, US Environmental Protection Agency, Washington, D.C., 2013.

Wigington Jr., P. J., Leibowitz, S. G., Comeleo, R. L., and Ebersole, J. L.: Oregon hydrologic landscapes: a classification framework, J. Am. Water Resour. Assoc., 49, 163-182, doi:10.1111/jawr.12009, 2013.

Winter, T. C.: The concept of hydrologic landscapes, J. Am. Water Resour. Assoc., 37, 335-349, 2001.

Wolock, D. M., Winter, T. C., and McMahon, G.: Delineation and evaluation of Hydrologic-Landscape Regions in the United States using Geographic Information System tools and multivariate statistical analyses, Environ. Manage., 34, S71-S88, doi:10.1007/s00267-003-5077-9, 2004. 